\title{
IASI carbon monoxide validation over the Arctic during POLARCAT spring and summer campaigns
}

\author{
M. Pommier ${ }^{1}$, K. S. Law ${ }^{1}$, C. Clerbaux ${ }^{1,3}$, S. Turquety ${ }^{2}$, D. Hurtmans ${ }^{3}$, J. Hadji-Lazaro ${ }^{1}$, P.-F. Coheur ${ }^{3}$, H. Schlager ${ }^{4}$, \\ G. Ancellet ${ }^{1}$, J.-D. Paris ${ }^{5}$, P. Nédélec ${ }^{6}$, G. S. Diskin ${ }^{7}$, J. R. Podolske ${ }^{8}$, J. S. Holloway ${ }^{9,10}$, and P. Bernath ${ }^{11,12}$ \\ ${ }^{1}$ UPMC Univ. Paris 06, Université Versailles St-Quentin, CNRS/INSU, UMR 8190, LATMOS-IPSL, Paris, France \\ ${ }^{2}$ UPMC Univ. Paris 06, Ecole Polytechnique, CNRS UMR 8539, LMD-IPSL, Palaiseau, France \\ ${ }^{3}$ Spectroscopie de l'Atmosphère, Chimie Quantique et Photophysique, Université Libre de Bruxelles (ULB), \\ Brussels, Belgium \\ ${ }^{4}$ DLR, Institut für Physik der Atmosphäre, Oberpfaffenhofen, Germany \\ ${ }^{5}$ LSCE/IPSL, CEA-CNRS-UVSQ, Saclay, France \\ ${ }^{6}$ Université de Toulouse, UPS, LA (Laboratoire d'Aérologie), CNRS UMR 5560, Toulouse, France \\ ${ }^{7}$ NASA Langley Research Center, MS 483, Hampton, USA \\ ${ }^{8}$ NASA Ames Research Center, Moffett Field, California, 94035, USA \\ ${ }^{9}$ Chemical Sciences Division, NOAA Earth System Research Laboratory, Boulder, Colorado, USA \\ ${ }^{10}$ Cooperative Institute for Research in Environmental Sciences, University of Colorado, Boulder, Colorado, USA \\ ${ }^{11}$ Department of Chemistry, University of Waterloo, Waterloo, Ontario, Canada N2L 3G1, Canada \\ ${ }^{12}$ Department of Chemistry, University of York, Heslington, York YO10 5DD, UK
}

Received: 22 April 2010 - Published in Atmos. Chem. Phys. Discuss.: 9 June 2010

Revised: 7 October 2010 - Accepted: 8 November 2010 - Published: 12 November 2010

\begin{abstract}
In this paper, we provide a detailed comparison between carbon monoxide (CO) data measured by the Infrared Atmospheric Sounding Interferometer (IASI)/MetOp and aircraft observations over the Arctic. The CO measurements were obtained during North American (NASA ARCTAS and NOAA ARCPAC) and European campaigns (POLARCAT-France, POLARCAT-GRACE and YAK-AEROSIB) as part of the International Polar Year (IPY) POLARCAT activity in spring and summer 2008. During the campaigns different air masses were sampled including clean air, polluted plumes originating from anthropogenic sources in Europe, Asia and North America, and forest fire plumes originating from Siberia and Canada. The paper illustrates that CO-rich plumes following different transport pathways were well captured by the IASI instrument, in particular due to the high spatial coverage of IASI. The comparison between IASI CO total columns, 0-5 km partial columns and profiles with collocated aircraft data was achieved by taking into account the different sensitivity and geometry of the sounding instruments. A detailed analysis
\end{abstract}

Correspondence to: M. Pommier (matthieu.pommier@latmos.ipsl.fr) is provided and the agreement is discussed in terms of information content and surface properties at the location of the observations. For profiles, the data were found to be in good agreement in spring with differences lower than $17 \%$, whereas in summer the difference can reach $20 \%$ for IASI profiles below $8 \mathrm{~km}$ for polluted cases. For total columns the correlation coefficients ranged from 0.15 to 0.74 (from 0.47 to 0.77 for partial columns) in spring and from 0.26 to 0.84 (from 0.66 to 0.88 for partial columns) in summer. A better agreement is seen over the sea in spring $(0.73$ for total column and 0.78 for partial column) and over the land in summer ( 0.69 for total columns and 0.81 for partial columns). The IASI vertical sensitivity was better over land than over sea, and better over land than over sea ice and snow allowing a higher potential to detect $\mathrm{CO}$ vertical distribution during summer.

\section{Introduction}

The Arctic atmosphere is a natural receptor of pollution from the continents of the Northern Hemisphere. The Arctic troposphere was believed to be extremely clean until the $1950 \mathrm{~s}$ when flights above the Canadian and Alaskan Arctic went

Published by Copernicus Publications on behalf of the European Geosciences Union. 
through strong haze, decreasing the visibility (Greenaway, 1950; Mitchell, 1957). This so-called "Arctic Haze" is a recurring phenomenon that has been observed every winter and spring. The origin of this pollution is long-range transport of aerosols and accumulation of persistent pollutants such as mercury and ozone $\left(\mathrm{O}_{3}\right)$. Recent studies (e.g. Shindell et al., 2008; Stohl, 2006) show that the Arctic troposphere is influenced, according to the season, by emissions from Europe, North America or Asia. These pollutants originate from large urban areas, as well as from boreal fires. Atmospheric pollution in this region may be having an effect on human health and also on climate through direct radiative effects or indirect effects such as enhanced summer sea-ice melt resulting from deposition of black carbon aerosols on snow and ice (Law and Stohl, 2007). Tropospheric ozone, an important greenhouse gas, could contribute, according to model simulations, to about $0.4^{\circ} \mathrm{C}$ to $0.5^{\circ} \mathrm{C}$ of winter and spring Arctic warming (Shindell et al., 2006). In the free troposphere, limited measurements such as those at Summit, Greenland, show a late spring/early summer ozone maximum (Helmig et al., 2007). Ozone can either be photochemically produced in mid-latitude source regions or during transport of pollution plumes to the Arctic. Transport of ozone rich-air from the upper troposphere or lower stratosphere is also a source. Carbon monoxide (CO) has been used in a number of studies as a tracer of pollution transport thanks to its relatively long lifetime of several weeks in the troposphere. In addition, CO is an important precursor of ozone through photochemical production, in the presence of nitrogen oxides $\left(\mathrm{NO}_{\mathrm{x}}\right)$. It is mainly produced from the combustion of fossil fuels by industry, car traffic or domestic heating system, and vegetation combustion or forest fires (e.g. Badr and Probert, 1995). It is also produced in the atmosphere following oxidation of methane $\left(\mathrm{CH}_{4}\right)$ and non-methane hydrocarbons (NMHCs) by hydroxyl radicals $(\mathrm{OH})$. Since its main sink is reaction with $\mathrm{OH}, \mathrm{CO}$ has an important role in the oxidizing power of the atmosphere, regulating the concentrations of $\mathrm{CH}_{4}$ and $\mathrm{O}_{3}$.

In recent decades many surface and in situ measurements have been made in the Arctic from ground stations, aircraft and balloon-borne platforms, providing observations of several trace species, including CO. Intensive field campaigns using airborne instrumentation often measure enough species to allow detailed analysis of the chemical composition of the air masses. Several past campaigns have sampled pollution transport events such as the Arctic Boundary Layer Expedition (ABLE) in 1988 (Harriss et al., 1992), the Tropospheric Ozone Production about the Spring Equinox (TOPSE) in 2000 (Atlas et al., 2003) and the International Consortium for Atmospheric Research on Transport and Transformation (ICARTT) in 2004 (Fehsenfeld et al., 2006). More recently, several aircraft campaigns were conducted in 2008 in the framework of the International Polar Year (IPY) focusing on pollutant transport (trace gas and aerosol), climate and Arctic tropospheric chemistry studies as part of the In- ternational Global Atmospheric Chemistry (IGAC) activity POLARCAT (Polar Study using Aircraft, Remote Sensing, Surface Measurements and Models, of Climate, Chemistry, Aerosols, and Transport). Observations from these aircraft campaigns, which were collected over a period of several weeks, provide a snapshot of Arctic chemical composition. They were complemented by satellite data which, even if their accuracy is lower, can provide global and continuous monitoring of the distributions of several trace gases, including CO. Satellite data have clearly shown long-range transport of CO plumes between continents (Turquety et al., 2007; Rinsland et al., 2007; McMillan et al., 2008; Yurganov et al., 2008; Fisher et al., 2010).

Among the satellite sounders probing $\mathrm{CO}$, the Infrared Atmospheric Sounding Interferometer (IASI) instrument, launched on board the polar-orbiting MetOp-A satellite on 19 October 2006, is the first of three consecutive instruments to be launched on the MetOp satellites. MetOp-A has a sunsynchronous orbit with a 09:30 local equator crossing time. With 14 daily orbits and a large scanning swath of $2200 \mathrm{~km}$ across the track, IASI provides global Earth coverage twice a day, and is thus particularly well suited for the analysis of long-range transport. Moreover, its polar orbit (inclination of $98.7^{\circ}$ ) allows enhanced coverage above the polar region. However, the nadir-viewing geometry implies limited vertical resolution, typically $\sim 6 \mathrm{~km}$ for $\mathrm{CO}$, with one to two independent pieces of information on the vertical distribution, depending mostly on surface temperature/thermal contrast (George et al., 2009; Clerbaux et al., 2009).

Satellite data need to be validated against independent measurements. The IASI CO total columns have recently been evaluated through comparisons with other satelliteborne instrument data (MOPITT, TES and AIRS) (George et al., 2009) and IASI was shown to perform well compared to other thermal infrared remote sensors. As yet, the IASI retrieved $\mathrm{CO}$ profiles have not been evaluated against in situ observations. In this paper, we evaluate the quality of the IASI CO data in the Arctic, taking advantage of the intensive aircraft campaigns as part of POLARCAT undertaken in 2008. Many in situ CO profiles were collected during landing, take-off, pollution exploration and during specific satellite validation flights. Specific difficulties associated with retrievals above the Arctic are investigated such as retrievals over ice, satellite observations above source regions as well as the seasonal variation of $\mathrm{CO}$ observations. Since the airborne observations are only performed up to $\sim 7-12 \mathrm{~km}$ (depending on the aircraft capabilities), the vertical profiles retrieved from the IASI nadir radiance measurements were compared with in situ profiles completed with a climatology built using limb CO profiles for different seasons and latitudes.

The paper is organized as follows: after an overview of the IASI CO retrievals over the Arctic (Sect. 2), the general context of the 2008 polar campaigns and details about the $\mathrm{CO}$ measurements used for the validation are given in 
Sect. 3. Section 4 describes the collocation criteria issue and the methodology adopted to validate IASI CO. Both a quantitative comparison and a statistical evaluation of the quality of the IASI CO retrievals in spring and summer 2008 are provided. Section 5 discusses further some of the interesting cases in terms of the spatial distribution of the observed plumes. Conclusions are presented in Sect. 6.

\section{IASI}

\subsection{CO retrievals}

IASI is a high resolution nadir looking thermal infrared (IR) sounder. It is a Fourier Transform Spectrometer (FTS) that records radiance measurements from the Earth's surface and the atmosphere with a high spectral resolution of $0.5 \mathrm{~cm}^{-1}$ (apodized) and spectrally sampled at $0.25 \mathrm{~cm}^{-1}$ over an extended spectral range from 645 to $2760 \mathrm{~cm}^{-1}$, and with a low radiometric noise $(0.2-0.35 \mathrm{~K}$ at $280 \mathrm{~K}$ reference). Global scale distributions of several species can be derived from the atmospheric spectra, such as $\mathrm{CO}, \mathrm{O}_{3}, \mathrm{HNO}_{3}, \mathrm{CH}_{4}, \mathrm{H}_{2} \mathrm{O}$, $\mathrm{NH}_{3}$ and other reactive trace gases (Clerbaux et al., 2009; George et al., 2009; Boynard et al., 2009; Wespes et al., 2009; Razavi et al., 2009; Herbin et al., 2009; Coheur et al., 2009; Clarisse et al., 2008). In addition, the dense horizontal coverage due to the large swath $(2200 \mathrm{~km})$ and the 14 daily orbits allow global Earth coverage twice a day, with each view being an atmospheric cell composed of $2 \times 2$ circular pixels each with a $\sim 12 \mathrm{~km}$ footprint diameter in nadir.

IASI CO distributions are retrieved from IASI radiance spectra $\left(2143-2181 \mathrm{~cm}^{-1}\right.$ spectral range) using the FORLICO (Fast Optimal Retrievals on Layers for IASI-CO) retrieval algorithm developed at the Université Libre de Bruxelles (ULB) (Turquety et al., 2009; George et al., 2009). The algorithm is based for the retrieval on the Optimal Estimation Method (OEM) described by Rodgers (2000). In addition to IASI spectra, the software uses the water vapour and temperature profiles from ECMWF (European Centre for Medium-Range Weather Forecasts) as input variables or from IASI level 2 operational data and distributed by EUMETSAT through the EUMETCAST dissemination system (Schluessel et al., 2005) as well as surface emissivity from the MODIS/Terra climatology (Wan, 2008). In this study, the temperature and water vapour profiles were taken from ECMWF analyses because the IASI retrieved data were not yet available.

The FORLI-CO algorithm provides $\mathrm{CO}$ profiles in volume mixing ratio (vmr) or partial column on 19 layers from the surface to the top of the atmosphere $(60 \mathrm{~km})$, each one kilometre thick, as well as error characterization diagnostics, including an a posteriori error variance-covariance matrix and an averaging kernel (AK) matrix. From these matrices a scalar error and a vector averaging kernel can be calculated, and are provided with the total column product.
The OEM seeks the optimal solution for the CO profile considering a given IASI radiance spectrum and the associated measurement error covariance matrix $\mathbf{S}_{\varepsilon}$. Since more than one solution can fit the observations, it is necessary to constrain the results with a priori information containing both the average value expected a priori profile $x_{\mathrm{a}}$, and the allowed variability around this average given by the socalled a priori covariance matrix $\mathbf{S}_{\mathrm{a}}$ (see Fig. 1). In order to build a matrix representative of both background and polluted conditions the a priori information was constructed using a database of $\mathrm{CO}$ profiles including aircraft profiles during landing and take-off from the MOZAIC (Measurements of OZone and water vapour by AIrbus in-service airCraft) program (Nédélec et al., 2003), ACE-FTS satellite observations in the upper troposphere and lower stratosphere (Clerbaux et al., 2005) and distributions computed by the LMDzINCA global chemistry-transport model (e.g. Turquety et al., 2008).

The OEM solution can be found by iteratively applying:

$\hat{x}_{i+1}=x_{\mathrm{a}}+\mathbf{D}_{\mathrm{y}}\left[y-F\left(\hat{x}_{i}\right)-\mathbf{K}_{i}\left(x_{\mathrm{a}}-\hat{x}_{i}\right)\right]$

With $\mathbf{D}_{\mathbf{y}}=\hat{\mathbf{S}}_{i} \mathbf{K}_{i}^{T} \mathbf{S}_{\varepsilon}^{-1}$ and $\hat{S}_{i+1}=\left(\mathbf{K}_{i+1}^{T} \mathbf{S}_{\varepsilon}^{-1} \mathbf{K}_{i+1}+\mathbf{S}_{a}^{-1}\right)^{-1}$. $\mathbf{K}_{i}$ is the Jacobian at state $x_{i}, \mathbf{K}_{i}^{T}$ is its transpose and $\hat{x}_{i+1}$ is the updated state vector. The matrix $\mathbf{D}_{\mathrm{y}}$ is known as the matrix of contribution functions. The error covariance of the solution is given by $\hat{S}_{i+1}$. The iteration starts with some initial estimate of the state, chosen to be the a priori information $x_{\mathrm{a}}$, of covariance $\mathbf{S}_{\mathrm{a}}$, and terminates when convergence has been reached.

The FORLI-CO total column products were validated by George et al. (2009) by comparison with other satellite retrievals. In the Northern Hemisphere, comparisons of IASI CO total columns with those of AIRS (Atmospheric InfraRed Sounder), MOPITT (Measurements Of Pollution in The Troposphere) and TES (Tropospheric Emission Spectrometer) show agreement to better than $\sim 7 \%$. MOPITT is higher than IASI with an average bias of $11.4 \%$ for data north of $45^{\circ} \mathrm{N}$. AIRS is in good agreement in the $\left[45^{\circ} ; 90^{\circ} \mathrm{N}\right]$ band (bias of $2.6 \%$ - correlation $\sim 0.85$ ) but in other regions discrepancies appear. AIRS CO data are larger than IASI at low concentrations $(\sim 11 \%)$ and lower at high concentrations $(\sim 17 \%)$. TES $\mathrm{CO}$ columns are globally lower than IASI (6.2\% for August 2008) (George et al., 2009). IASI columns were also evaluated in Turquety et al. (2009) for biomass burning plumes.

To characterize vertical sensitivity and resolution of IASI CO retrievals, the AK matrix and the Degree Of Freedom for Signal (DOFS) are used (Rodgers et al., 2000). DOFS represents the number of independent levels that can be retrieved and corresponds to the trace of the AK matrix. The latter can be viewed as a weighting function characterizing the vertical sensitivity of each $\mathrm{CO}$ measurement with the remainder of the information provided by the a priori profile. The study by George et al. (2009) showed that IASI CO retrievals have between 0.8 and 2.4 pieces of independent vertical information. When DOFS are below 1.0 profiles are contaminated by 


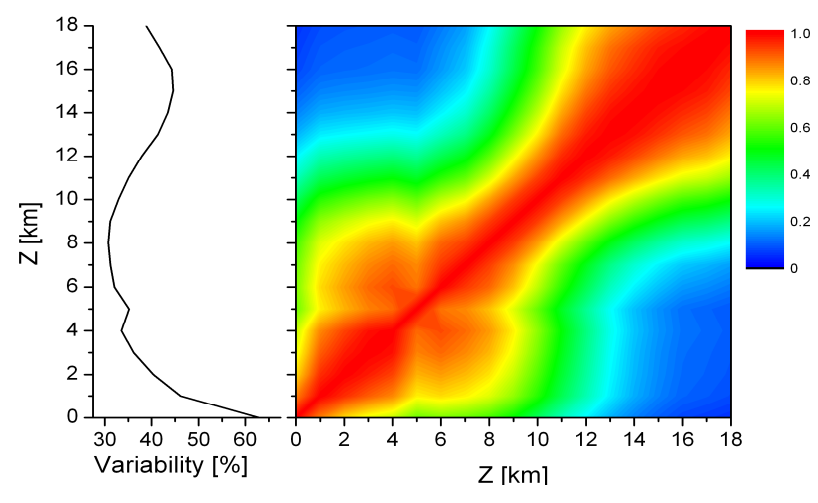

Fig. 1. Variability of a priori $\mathrm{CO}$ in percent and correlations matrix obtained from covariance matrix $\mathbf{S}_{\mathrm{a}}$ used in the FORLI-CO retrieval algorithm.

the a priori contribution whereas above 1.0 the resolution of the profiles is better than a tropospheric column. Examples of IASI sensitivity are reported in George et al. (2009).

\subsection{Performance of IASI retrievals in the Arctic}

In the Arctic, the DOFS is generally low due to the cold surface temperatures. Higher DOFS are obtained when thermal contrast is important (Clerbaux et al., 2009) and the latter varies as a function of the surface type and the diurnal surface temperature contrast. This second effect is illustrated in Fig. 2, representing the diurnal variability of a mean averaging kernel over Siberia in July 2008. Over the area relevant to this work (mid to high latitudes), and as shown in Fig. 3, the DOFS ranged from 0.6 to 2.2 during the day and from 0.3 to 2.0 during the night in April 2008. Daytime corresponds to a solar zenith angle (SZA) lower or equal to $83^{\circ}$ and nighttime to a SZA higher or equal to $90^{\circ}$. In July 2008 , the DOFS ranged from 1.0 to 2.3 in daytime and 0.9 to 2.2 at night. It is worth noting that due to orographic effects, small DOFS values are found over Greenland in spring and Northern China close to Mongolia in summer.

Figure 4 shows a monthly averaged distribution of the root-mean-square (RMS) error of the differences between observed and fitted spectra. This characterizes the uncertainty in the retrieval (see Turquety et al., 2009), as well as the associated mean difference (bias), which is expressed as a percentage of the total RMS for daytime in both seasons. This bias corresponds to the mean of the absolute values of the residuals. It shows if residuals are well centered around zero. The RMS includes errors due to radiometric noise, the forward model (radiative transfer), in particular due to uncertainties in the temperature and water vapour profiles, aerosol contamination (although it is expected to be low in the CO spectral range), as well as uncertainties in the $\mathrm{CO}$ adjusted profile. High RMS values are observed over land, especially in summer. Large

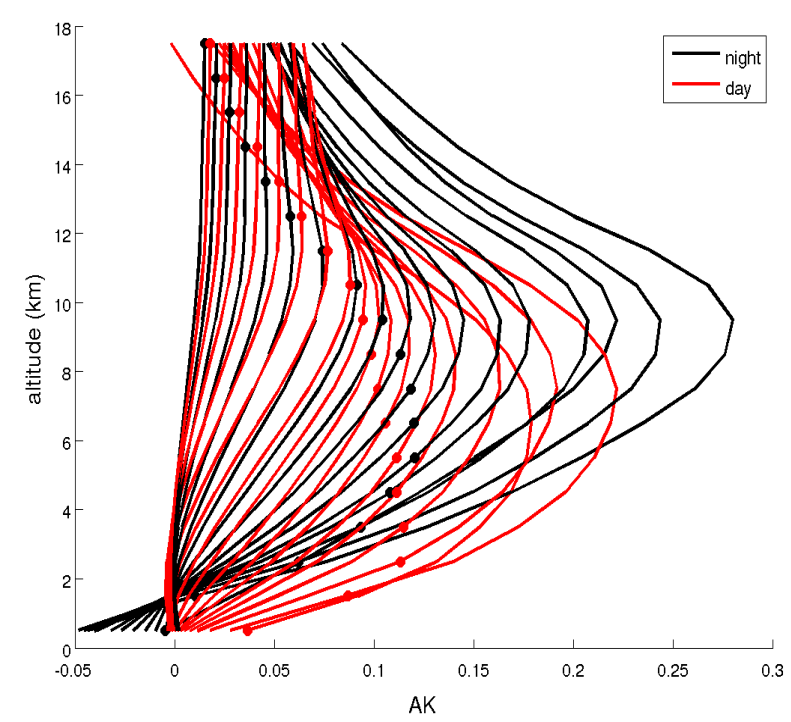

Fig. 2. Monthly mean of IASI averaging kernel for July 2008 over Siberia $\left(100-140^{\circ} \mathrm{E}, 50-70^{\circ} \mathrm{N}\right)$ during daytime (red) and nighttime (black). The dots on the averaging kernel show the corresponding altitude.

errors are associated with emissivity issues due to sand over deserts (Sahara, Nevada or Gobi desert). Note that in the Turquety et al. (2009) study, data with RMS higher than $3.5 \times 10^{-9} \mathrm{~W} /\left(\mathrm{cm}^{2} \mathrm{~cm}^{-1} \mathrm{sr}\right)$ were filtered out. Such high RMS values are not encountered in the Arctic region, where they range from 1.19 to $1.40 \times 10^{-9} \mathrm{~W} /\left(\mathrm{cm}^{2} \mathrm{~cm}^{-1} \mathrm{sr}\right)$ in April and 1.45 to $1.70 \times 10^{-9} \mathrm{~W} /\left(\mathrm{cm}^{2} \mathrm{~cm}^{-1} \mathrm{sr}\right)$ in July, north of $45^{\circ} \mathrm{N}$, during the day (inter-quartile range). Table 1 summarizes the IASI performance over three emission regions impacting the Arctic (North America, Asia, Europe), and two receptors regions (Pacific Ocean and North Pole) for both daytime and night-time conditions. Over each region, polluted conditions, where the $\mathrm{CO}$ total columns are higher or equal to $3 \times 10^{18}$ molecules $/ \mathrm{cm}^{2}$ and the background conditions, where the total columns are lower than $3 \times 10^{18}$ molecules $/ \mathrm{cm}^{2}$ were separated and used to calculate means and standard deviations. The overall RMS is around $1.5 \times 10^{-9} \mathrm{~W} /\left(\mathrm{cm}^{2} \mathrm{~cm}^{-1} \mathrm{sr}\right)$ during the day and the night in April and around $1.8 \times 10^{-9} \mathrm{~W} /\left(\mathrm{cm}^{2} \mathrm{~cm}^{-1} \mathrm{sr}\right)$ in July. During both these periods higher RMS and biases (not shown) were found for polluted conditions compared to background conditions.

\section{POLARCAT campaigns: data used for IASI validation}

As part of POLARCAT, several aircraft campaigns were carried out in spring and summer 2008. Each campaign had its own particular goals as well as the general goal of improving our knowledge about sources, transport pathways 

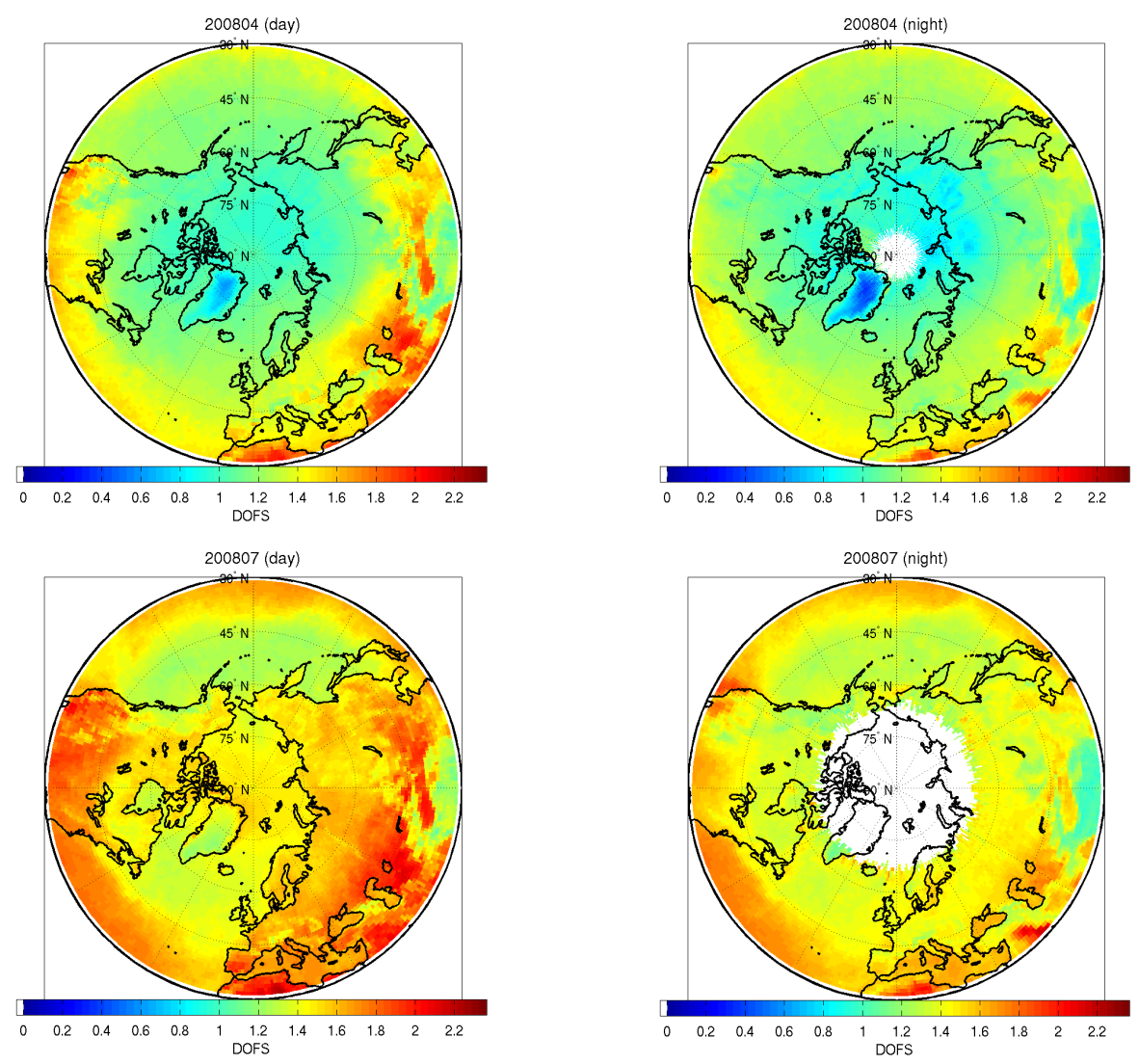

Fig. 3. IASI DOFS monthly maps on a $1^{\circ} \times 1^{\circ}$ grid for April 2008 (top panels) and July 2008 (bottom panels) for daytime (left) and night-time (right).

and climate impacts of Arctic pollution. Here, we provide brief details about these campaigns and the $\mathrm{CO}$ measurements used in this study for validating IASI CO data. The different $\mathrm{CO}$ measurements on board all the aircraft used for this validation exercise are listed in Table 2 including information about measurement precision and accuracy. All the flights used for comparison with the IASI CO retrievals are shown in Fig. 5, superimposed on the IASI monthly averaged total column CO map $\left(1^{\circ} \times 1^{\circ}\right.$ grid $)$ for April and July 2008. For both seasons, spring and summer, the validation made use of all flights including the transit flights and flights from the ARCTAS-CARB (California Air Resources Board) deployment over California from 18 to 24 June 2008, and described in Jacob et al. (2010). According to the seasons and flight areas, different types of air mass were sampled, primarily in the free troposphere but sometimes in the boundary layer or lower stratosphere. These included clean air, polluted plumes originating from anthropogenic sources in Europe, Asia and North America, and forest fires plumes from Siberia and Canada. The IASI CO data used in this validation exercise were accumulated during both morning and afternoon orbits. Data collected were mainly in daytime especially at high latitudes during polar summer, reducing the impact on the comparisons of diurnal variation of thermal contrast.

\subsection{POLARCAT-France and POLARCAT-GRACE}

The POLARCAT-France campaigns took place between 30 March and 14 April 2008, from Kiruna, northern Sweden, and between 30 June and 14 July 2008 from Kangerlussuaq on the western coast of Greenland. The main objectives of the POLARCAT-France spring campaign were to study the Arctic front, transport of European and Asian (Siberian) pollutants to the Arctic and aerosol-cloud interactions and their impact on aerosol radiative forcing (Adam De Villiers et al., 2010). On the other hand, the summer campaign was mainly dedicated to the study of transport of boreal forest fires and anthropogenic emissions and their impact on Arctic chemical composition. Aerosol properties, $\mathrm{O}_{3}, \mathrm{H}_{2} \mathrm{O}$ and $\mathrm{CO}$ were measured by the French ATR-42 aircraft as well as $\mathrm{O}_{3}$ and aerosol lidar measurements. The $\mathrm{CO}$ payload on the French ATR-42 used an IR absorption gas correlation with modified commercial gas analysers Thermo $48 \mathrm{C}$ and Thermo 49 (Thermo Environmental Instruments, USA) as in the MOZAIC program (Nédélec et al., 2003). Its accuracy 

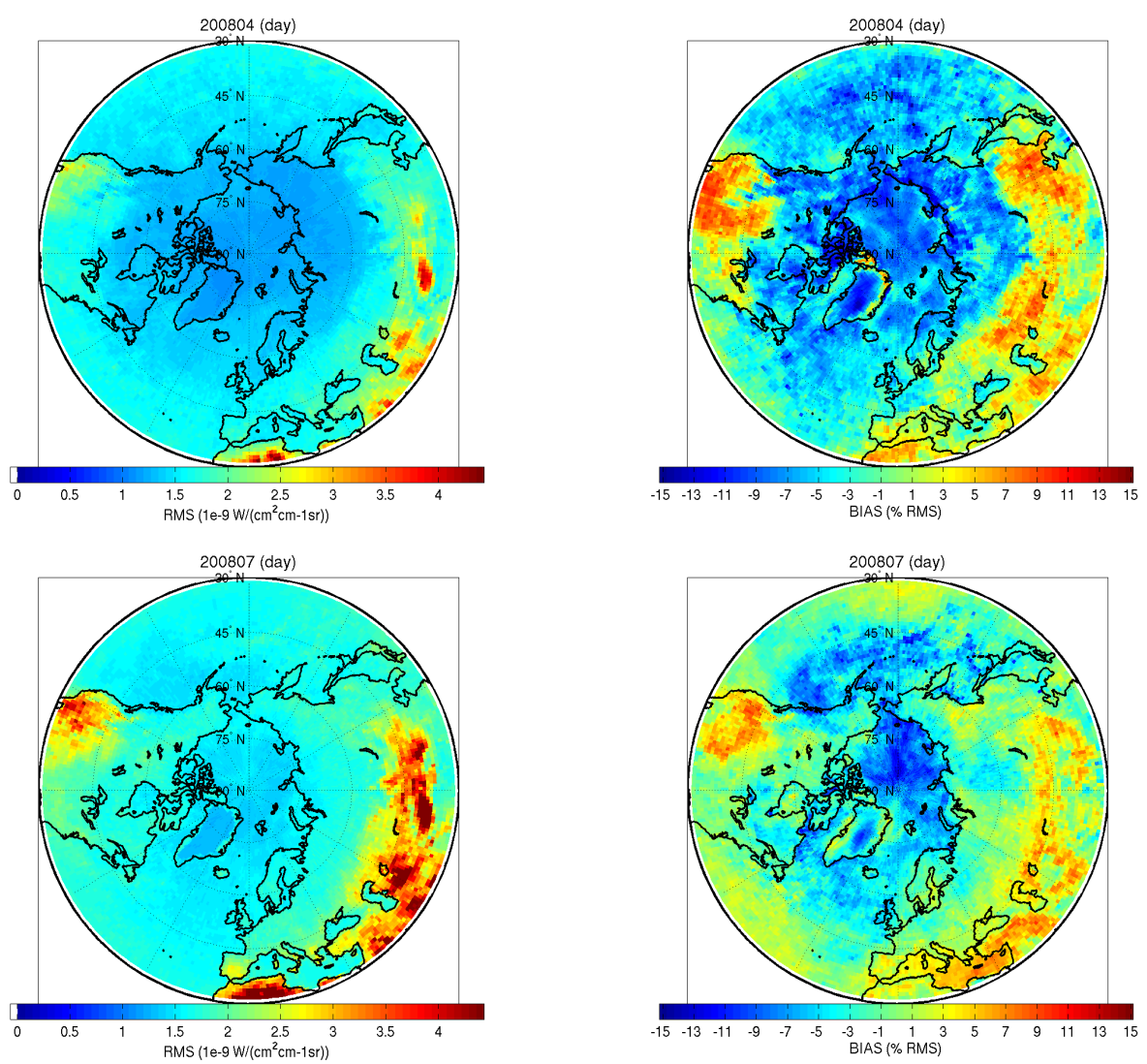

Fig. 4. Maps of IASI daytime root mean square (RMS) error between the observed and the fitted spectrum (left panels), and bias (RMS percentage) (right panels). Plots are monthly means for April 2008 (top) and July 2008 (bottom). Data are on a $1^{\circ} \times 1^{\circ}$ grid.
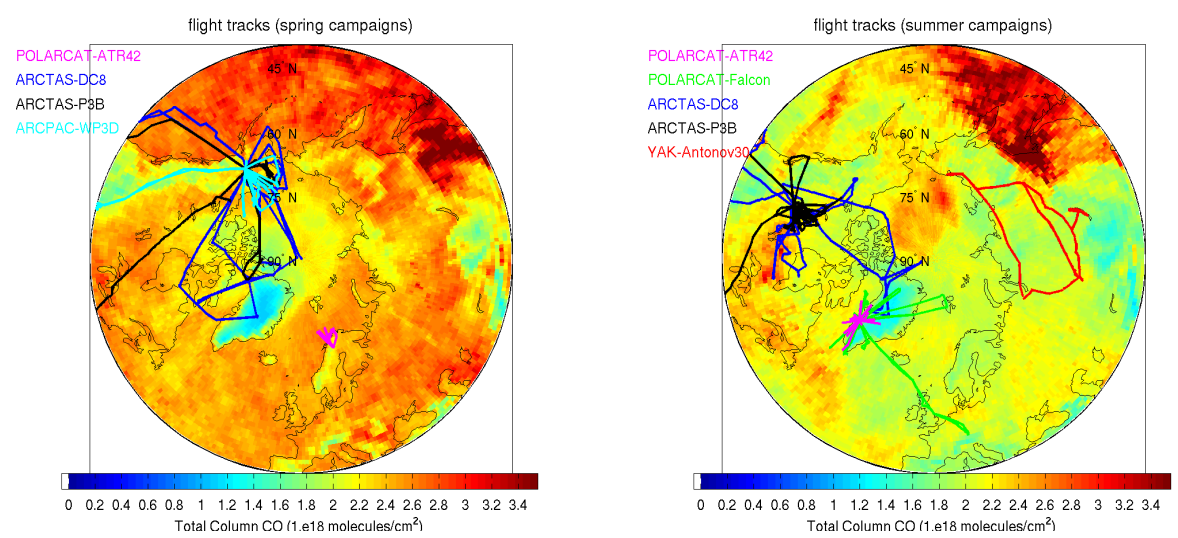

Fig. 5. Overview of all flights of DC-8 (blue), P-3B (black), ATR-42 (magenta), WP-3D (cyan), Falcon (green), Antonov-30 (red) aircraft during POLARCAT spring (left map) and the summer (right map) campaigns superimposed on IASI CO total column monthly mean maps (daytime) for April and July 2008. The IASI CO data are averaged over $1^{\circ} \times 1^{\circ}$.

has been improved by the addition of periodical zero measurements. The instrument is calibrated with a $\mathrm{CO}$ standard referenced by NIST (National Institute of Standards and Technology) at $\pm 1 \%$. A comparison with the DLR Falcon20 data revealed a 7 ppbv negative difference between the
ATR-42 and the Falcon-20. This was already noted in previous studies (Ancellet et al., 2009) and related to differences in the calibration standard. During the spring and summer campaigns, specific IASI validation flights were performed. For these IASI validation flights, the ATR-42 made spirals 
Table 1. Summary of the performance of the fits in terms of CO total columns, residual RMS and DOFS. For each case, the average and standard deviation over the regions of reference is provided. The regions are defined as: Pacific Ocean $\left(\left[130180^{\circ} \mathrm{W}\right] ;\left[4055^{\circ} \mathrm{N}\right]\right)$,

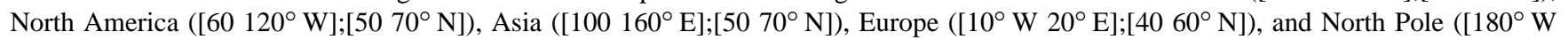
$\left.\left.180^{\circ} \mathrm{E}\right] ;\left[7590^{\circ} \mathrm{N}\right]\right)$.

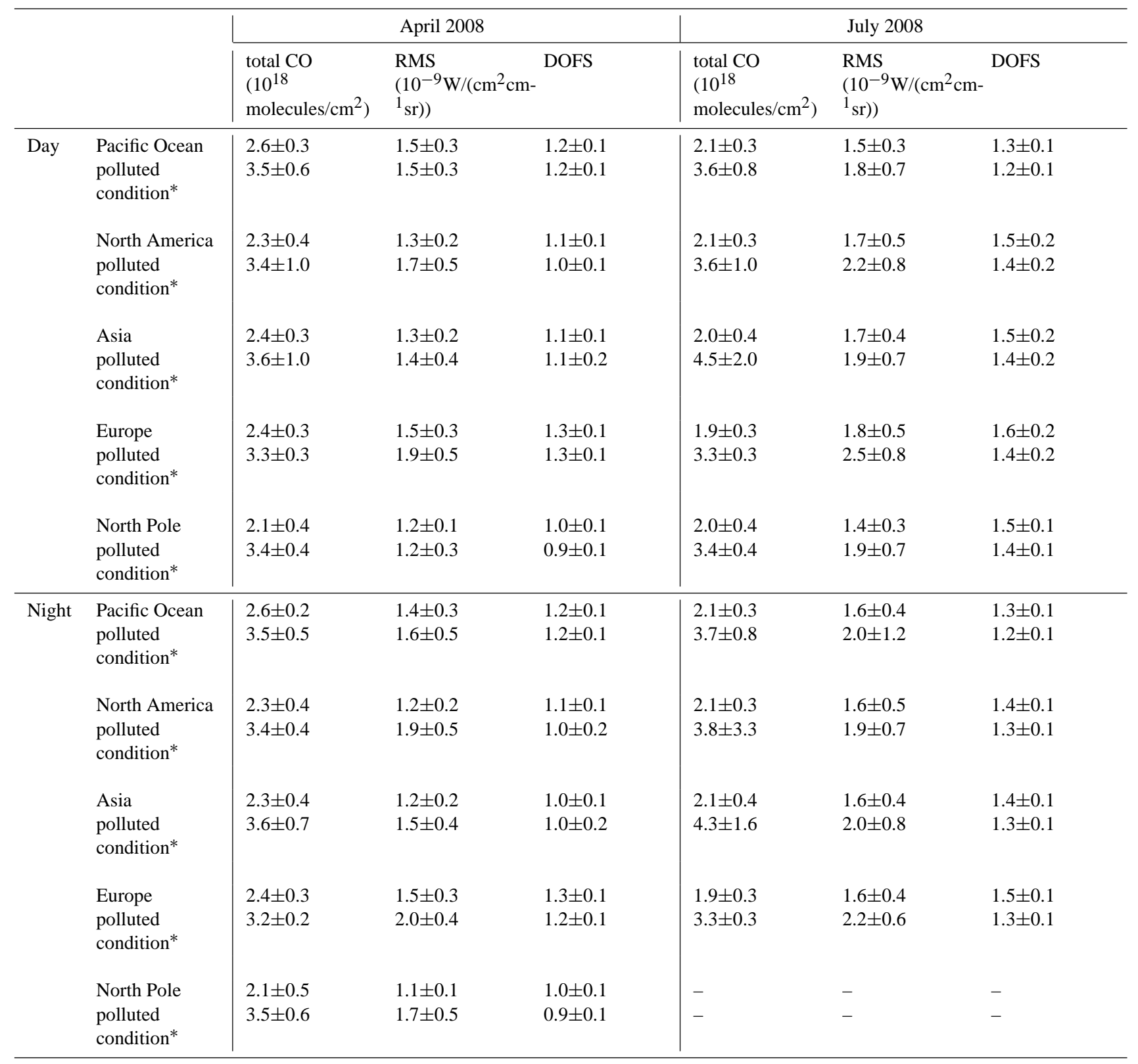

* Polluted conditions are when columns CO exceed $3 \times 10^{18}$ molecules $/ \mathrm{cm}^{2}$.

during profiles. These profiles were made in the IASI scanning area close to the satellite overpass time.

During summer 2008 there was also the German POLARCAT-GRACE (GReenland Aerosol and Chemistry Experiment) campaign based at Kangerlussuaq, western Greenland, using the DLR Falcon-20 (30 June to 18 July 2008). The Falcon- 20 measurements included $\mathrm{O}_{3}, \mathrm{CO}, \mathrm{CO}_{2}$, $\mathrm{H}_{2} \mathrm{O}, \mathrm{NO}, \mathrm{NO}_{2}, \mathrm{PAN}, \mathrm{NO}_{\mathrm{y}}, j\left(\mathrm{NO}_{2}\right)$ and aerosol concentration and size. $\mathrm{CO}$ was measured with vacuum ultraviolet
(UV) fluorescence technique using an AEROLASER instrument (Baehr et al., 2003).

In general, during these POLARCAT campaigns, flights sampled clean air, anthropogenic pollution from Europe and Asia (in spring), North America and Asia pollution (in summer), biomass burning plumes from Canada and Siberia, and often, a mixture of anthropogenic and forest fires plumes. 
Table 2. Summary of CO measurements onboard 6 aircraft involved during ARCTAS (DC-8, P-3B), ARCPAC (WP-3D), POLARCAT (ATR-42, Falcon-20) and YAK-AEROSIB (Antonov-30) campaigns.

\begin{tabular}{|c|c|c|c|c|c|c|}
\hline Aircraft & Reference & Technique & Averaging time & Accuracy & Precision & Detection limit \\
\hline DC-8 & Sachse et al. (1987) & TDLAS & $1 \mathrm{~s}$ & $2 \%$ & $1 \mathrm{ppb}$ & N/A \\
\hline P-3B & Provencal et al. (2005) & ICOS & $1 \mathrm{~s}$ & $2 \%$ & $2 \mathrm{ppb}$ & $3 \mathrm{ppb}$ \\
\hline WP-3D & Holloway et al. (2000) & VUV fluorescence & $1 \mathrm{~s}$ & $1 \%$ & $2 \mathrm{ppb}$ & $2 \mathrm{ppb}$ \\
\hline ATR-42 & Nédélec et al. (2003) & IR absorption correlation gas analyser & $30 \mathrm{~s}$ & $5 \%$ & $5 \mathrm{ppb}$ & $10 \mathrm{ppb}$ \\
\hline Falcon-20 & Baehr et al. (2003) & UV fluorescence & $4 s$ & $5 \%$ & $2 \mathrm{ppb}$ & $2 \mathrm{ppb}$ \\
\hline Antonov-30 & $\begin{array}{l}\text { Nédélec et al. (2003), } \\
\text { Paris et al. (2008) }\end{array}$ & IR absorption correlation gas analyser & $30 \mathrm{~s}$ & $5 \%$ & $5 \mathrm{ppb}$ & $10 \mathrm{ppb}$ \\
\hline
\end{tabular}

\subsection{ARCPAC-ARCTAS}

The Aerosol, Radiation, and Cloud Processes affecting Arctic Climate (ARCPAC) mission was conducted by NOAA (Warneke et al., 2009). This experiment was coordinated as part of the overall POLARCAT mission and the NOAA baseline climate research station at Barrow. The campaign took place from 3 to 23 April 2008, based in Fairbanks, Alaska. Transit flights were on 3 and 23 April and research flights from Fairbanks from 11 to 21 April. The campaign investigated the chemical, optical and microphysical characteristics of aerosols and gas phase species in the Arctic springtime to determine the origin of sources (Warneke et al., 2009). The instrumentation on board the aircraft was dedicated to $\mathrm{CO}$, $\mathrm{CO}_{2}, \mathrm{H}_{2} \mathrm{O}, \mathrm{NO}, \mathrm{NO}_{2}, \mathrm{NO}_{\mathrm{y}}, \mathrm{PANs}, \mathrm{SO}_{2}$, VOC and halogen measurements. Moreover, aerosol speciation (AMS), optical extinction, and black carbon measurements were also made, in addition to the microphysical properties. The NOAA ARCPAC WP-3D aircraft used a vacuum UV fluorescence instrument to measure CO (Holloway et al., 2000).

Arctic Research of the Composition of the Troposphere from Aircraft and Satellites (ARCTAS) was directed by NASA (Jacob et al., 2010; Fischer et al., 2010) with flight campaigns conducted in spring and summer 2008 as part of ARCTAS-A and ARCTAS-B with flights of the NASA DC8 and P-3B. During the spring campaign based in Fairbanks, Alaska, flights focused on Arctic haze detection, aerosol radiative forcing and anthropogenic pollution studies, dovetailing the objectives of ARCPAC. The summer campaign, based in Cold Lake, Canada, focused on boreal forest fires and long-range transport impacts on the Arctic atmosphere. On board the DC-8 many measurements were performed including aerosol properties, black carbon (BC), $\mathrm{SO}_{2}$, peroxy acetic acid, acetaldehyde, acetone, acetonitrile, benzene, isoprene, methanol, toluene, $\mathrm{Hg}, \mathrm{CO}, \mathrm{O}_{3}, \mathrm{CH}_{2} \mathrm{O}, \mathrm{H}_{2} \mathrm{O}_{2}, \mathrm{H}_{2} \mathrm{O}$, $\mathrm{HO}_{2}, \mathrm{HCN}, \mathrm{OH}, \mathrm{HNO}_{3}, \mathrm{PAN}, \mathrm{NO}, \mathrm{NO}_{2}, \mathrm{NO}_{\mathrm{y}}$, and $\mathrm{H}_{2} \mathrm{SO}_{4}$ (Jacob et al., 2010). Measurements of $\mathrm{CO}$ on the NASA DC-8 as part of ARCTAS were made using a tunable diode laser absorption (TDLAS) (Sachse et al., 1987) whilst measurements on the P-3B were made using the COBALT instrument, which employs off-axis Integrated Cavity Output Spectroscopy (oa-ICOS) (Provencal et al., 2005).

\subsection{YAK-AEROSIB}

As part of a joint French-Russian project, YAK-AEROSIB (Airborne Extensive Regional Observations in Siberia), flights were made in July 2008 with a Russian Antonov-30 over Siberia (Paris et al., 2009), and consisted of two large loops over northern and central Siberia. Flight routes, fixed six months before the campaign, were chosen with the aim of sampling boreal forest fire plumes. The most significant fire plumes were encountered on 11 July 2008 (Paris et al., 2009). During YAK-AEROSIB flights, aerosol number, $\mathrm{CO}_{2}, \mathrm{CO}$, $\mathrm{O}_{3}$, and $\mathrm{H}_{2} \mathrm{O}$ were measured (Paris et al., 2008). $\mathrm{CO}$ was also measured by similar instrumentation to that on the French ATR-42 using IR absorption gas correlation (Nédélec et al., 2003; Paris et al., 2008).

\section{Quantitative comparison between IASI and in situ profiles}

\subsection{Collocation criteria}

In order to compare satellite observations and aircraft measurements, an important first step is to check the place and time coincidence. Different coincidence criteria around the flight position were tested (from $\pm 0.2^{\circ}, \pm 1 \mathrm{~h}$ to $\pm 0.5^{\circ}, \pm 2 \mathrm{~h}$ ) and here, comparisons were conducted using a stringent collocation criterion, i.e. a box of $0.2^{\circ} \times 0.2^{\circ}$ and time of $\pm 1 \mathrm{~h}$. When the criteria were relaxed it appeared that IASI CO signatures were less visible and results from the comparisons were not improved. According to the stringent criteria used hereafter, the number of collocations per flight varies from 40 to 162 in spring and from 27 to 128 for the summer campaigns. This number also depends on the area covered by the aircraft, the duration of the flights and the cloud cover in the sampling area. The largest number of coincidences was obtained for the American flights during the spring campaigns, due to their polar exploration and the good coverage of the MetOp polar orbit at these high latitudes. 


\subsection{Methodology}

A quantitative comparison requires a specific consideration of instrumental and retrieval characteristics. For a proper comparison of satellite data with in situ measurements, the transformation of the in situ profile with the averaging kernel and the a priori profile is required in order to take into account the sensitivity of the retrieval to the true profile (Rodgers and Connor, 2003). The retrieved profile was obtained as follows,

$x_{\text {retrieved }}=\mathbf{A}_{\text {low }} x_{\text {high }}+\left(\mathbf{I}-\mathbf{A}_{\text {low }}\right) x_{\mathrm{a}, \text { low }}$

where $\mathbf{A}_{\text {low }}$ represents the AK matrix characterizing the low resolution profiles, $x_{\text {high }}$ the true profile (interpolated to the low resolution profiles levels) and $x_{\mathrm{a} \text {,low }}$ the a priori profile. In situ measurements were convolved with the IASI AK using Eq. (2). The aircraft profiles used in this validation exercise were recorded either during specific validation flights (e.g. ATR-42 on 3 April 2008), during take-off or landing or during deep vertical profiles in any flight. The IASI AK was applied to each in situ $\mathrm{CO}$ vertical profile in order to smooth the better resolved profiles before comparison with co-located IASI data. Since most co-located $\left[ \pm 0.2^{\circ} ; \pm 1 \mathrm{~h}\right]$ aircraft profiles were limited in altitude (compared to the full satellite profile), and in order to use the full AK matrix, the in situ profiles were extended using $\mathrm{CO}$ profiles retrieved from the ACE-FTS instrument in the upper troposphere and above as described in the next section.

\subsection{ACE-FTS CO measurements used for IASI validation}

ACE-FTS (Fourier Transform Spectrometer) is the main instrument of Atmospheric Chemistry Experiment (ACE) mission, launched on board the Canadian SCISAT-1 satellite on 12 August 2003 (Bernath et al., 2005). It uses a Fourier Transform Spectrometer measuring IR radiation in solar occultation mode to observe vertical profiles of numerous trace species (Bernath et al., 2005; Coheur et al., 2007). Daily ACE-FTS measurements are obtained for up to fifteen sunrises and fifteen sunsets every $24 \mathrm{~h}$ and $\mathrm{CO}$ profiles are retrieved by analysing occultation sequences (Boone et al., 2005; Clerbaux et al., 2005, 2008). This processing uses a global-fit method in a general non-linear least squares minimization scheme and a set of micro-windows that vary with altitude in the fundamental 1-0 rotation-vibration band (around $4.7 \mu \mathrm{m})$ and in the overtone 2-0 band $(2.3 \mu \mathrm{m})$. The intense 1-0 band provides information in the upper atmosphere and the 2-0 band at lowest altitudes when the signal from fundamental band saturates. In this paper, we used version 2.2 of the $\mathrm{CO}$ operational retrievals for the spring and summer to build a climatology to complement the in situ measurements for the IASI CO validation.

All available ACE-FTS profiles from 2004 to 2009 were used to compile seasonally averaged profiles for 15 degrees latitude bins up to $60 \mathrm{~km}$ (same maximum altitude as IASI profiles). We used ACE-FTS data representative of each season, February to May for spring, and June to September for summer. Only profiles where there was no gap between the aircraft maximum altitude and the ACE-FTS minimum altitude were used in the validation procedure. The maximum altitudes reached by the different aircraft were $7 \mathrm{~km}$ for ATR42 and WP-3D, $8 \mathrm{~km}$ for Antonov-30 and P-3B, $11 \mathrm{~km}$ for the Falcon-20 and $12 \mathrm{~km}$ for DC-8, respectively. Moreover, between 7 and $12 \mathrm{~km}$ this climatology shows a good coherence with sample of in situ measurements onboard aircraft flying in this altitude range.

\subsection{Results: comparison of selected representative profiles}

Figure 6 shows an example of an in situ profile convolved with the IASI AK and a reconstructed profile obtained by combining in situ and ACE-FTS measurements, also convolved with the IASI AK. This observation was made during the ATR-42 flight on 3 April 2008 during an IASI validation profile above the sea at $71^{\circ} \mathrm{N}$ and $22^{\circ} \mathrm{E}$. For this case the DOFS was $\sim 1.15$ with a maximum sensitivity between 1 to $8 \mathrm{~km}$ and therefore, this measurement is best represented by a tropospheric column. It can be seen that when combined with the ACE-FTS climatology (and so applying the full AK matrix), the smoothed in situ profile is closer to the retrieved values from IASI. In the following we will refer to aircraft profiles completed using the ACE-FTS climatology (and convolved with IASI AK) as "smoothed in situ profiles". We compared the smoothed in situ and IASI measurements both in terms of mixing ratio profiles and total columns (sum of partial columns). A systematic comparison was performed for all flights. Figures 7 and 8 respectively, show examples of comparisons in spring and summer, from specific flights highlighting different sampling conditions including surface type. Figure 9 shows the position of these profiles on a landsea-ice map.

\subsubsection{Spring cases}

Figure 7a shows a CO profile above the Chukchi Sea, close to the Alaskan coast, on 9 April (see Fig. 9a). The sea was frozen at this time and IASI did not distinguish the $\mathrm{CO}$ variability and the high signature around 5-6 km ( $185 \mathrm{ppbv})$. Even if the plume altitude is located at levels where IASI has good sensitivity, the signal is mixed with other layers since it corresponds to a DOFS close to 1 , so that the plume is smoothed out. Nevertheless, after accounting for the limited IASI sensitivity, the agreement between smoothed in situ and IASI is good with a maximum difference between both profiles of $2.3 \mathrm{ppbv}$ at $0.5 \mathrm{~km}$ in the in situ part (below $8.5 \mathrm{~km}$ ) and of $6.4 \mathrm{ppbv}$ at $12.5 \mathrm{~km}$, where the ACEFTS climatology was used. In case (b) the aircraft measured an aged Siberian biomass burning plume over sea ice 

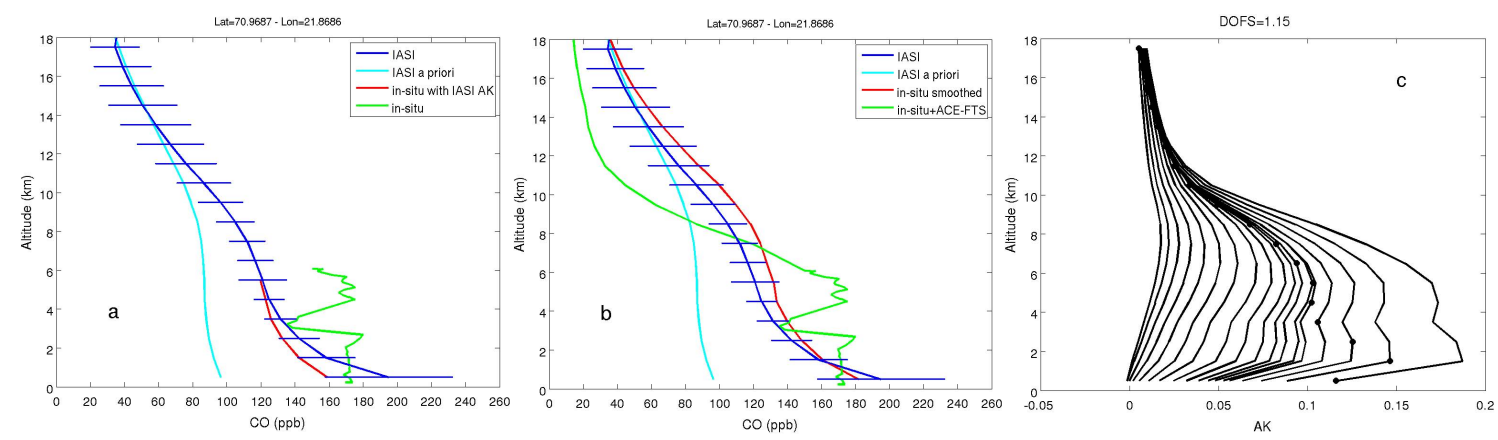

Fig. 6. CO profiles during ATR-42 validation flight on 3 April 2008 at $71^{\circ} \mathrm{N}$ and $22^{\circ}$ E. Volume mixing ratio profiles (in ppbv) from IASI (blue) compared with in situ measurements (a) and in situ plus ACE-FTS climatology (green) (b). The cyan line is the IASI a priori and the red line is the in situ smoothed profile. The IASI error bars correspond to retrievals errors. The IASI averaging kernel is shown in (c). The black dots on the averaging kernel show the corresponding altitude.

(a) DC-8 20080409

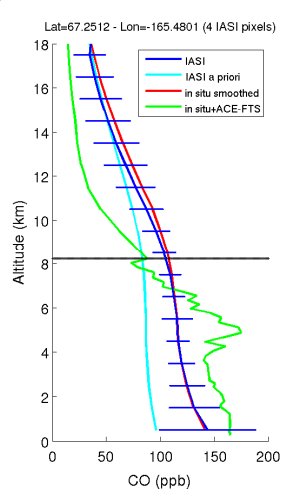

(c) ATR-42 20080410

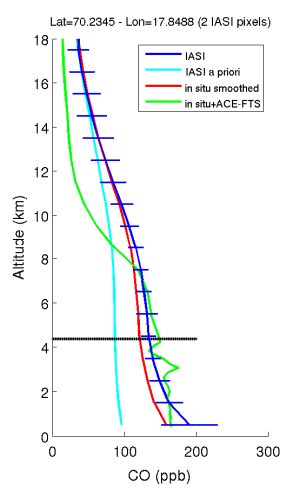

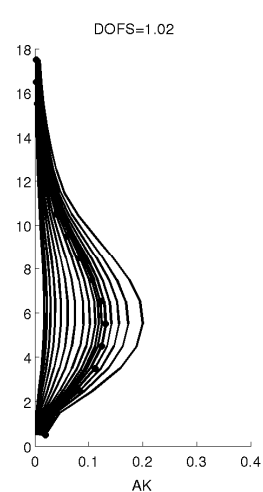

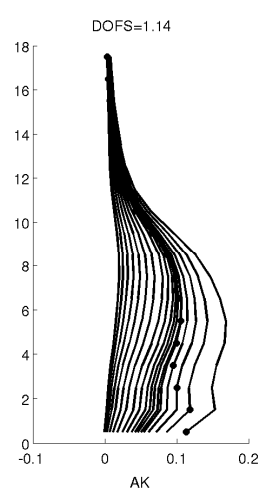

(b) WP-3D 20080418
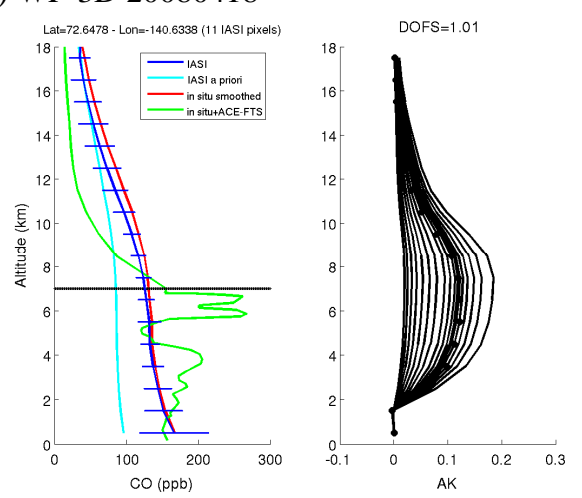

(d) ATR-42 20080331
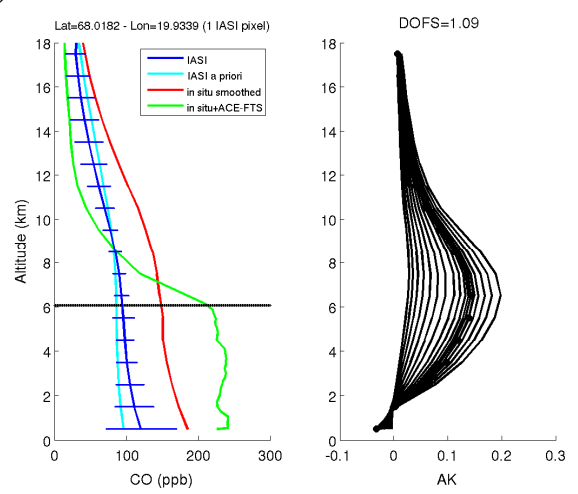

Fig. 7. CO profiles (in ppbv) of IASI (blue) and in situ measurements completed with ACE-FTS climatology (green) and convolved with IASI AK (red) for four examples in spring. The cyan line is the IASI a priori. For each example, the IASI averaging kernel is also plotted with the black dots showing the corresponding altitude. The IASI errors bars correspond to retrievals errors. The horizontal black line represents the flight ceiling of the aircraft in the in situ profile. In situ profiles were measured by the DC-8 on 9 April (a), by the WP-3D on 18 April (b), the ATR-42 on 10 April (c) and on 31 March (d). See text for details.

(Warneke et al., 2009) (see Fig. 9a for the location). This flight is discussed further in Sect. 5.2.1. In this example, the retrieval fully smoothes out the $\mathrm{CO}$ enhancements observed between $2-4 \mathrm{~km}$ and $6-7 \mathrm{~km}$. This smoothing is clearly due to the lack of vertical sensitivity with a DOFS $\sim 1.0$. Nevertheless the agreement between the IASI and the smoothed in situ profiles is good (difference always below 12 ppbv). The third example (case (c)) was measured over the sea close to the western Norwegian coast by the ATR42 on 10 April. Over this area, the sea was not frozen (see 
(a) DC-8 20080705

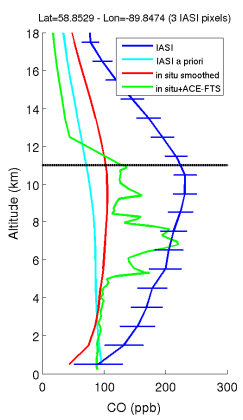

(b) An

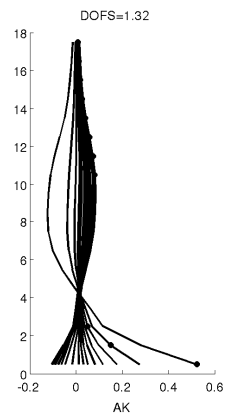

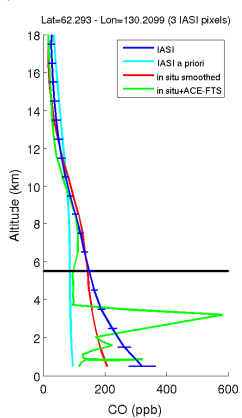

(c) ATR-42 20080710

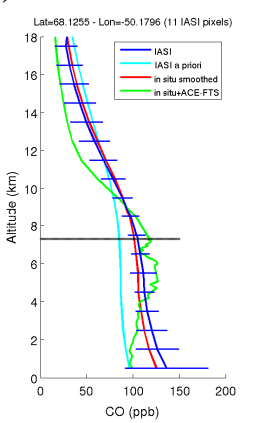

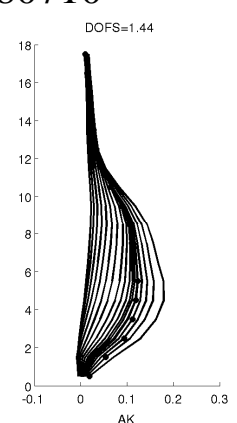

Fig. 8. Same as Fig. 7 for three examples in summer. In situ profiles were measured by the DC-8 on 5 July (a), the Antonov-30 on 11 July (b), and the ATR-42 10 July 2008 (c). See text for details.

a)

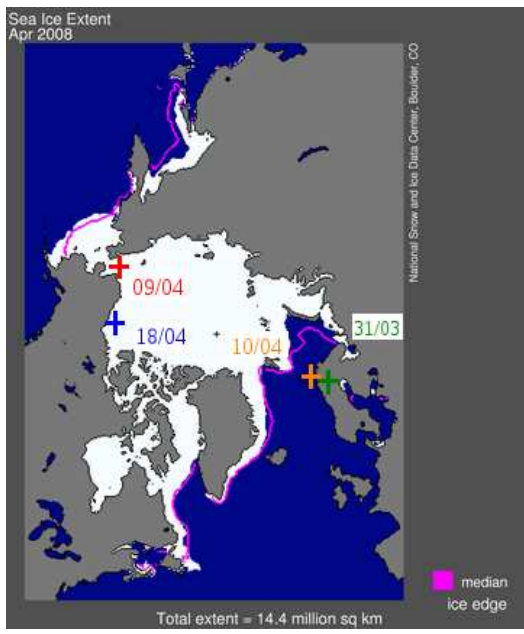

b)

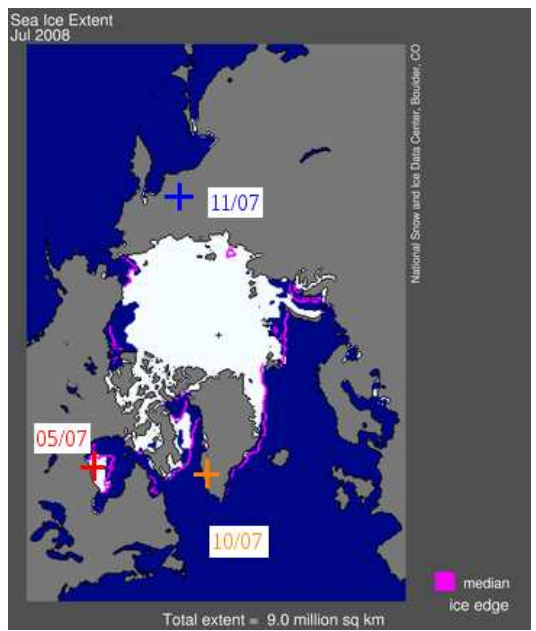

Fig. 9. Monthly averaged sea ice cover maps (white area) for April (a) and July 2008 (b). The magenta line shows the 1979 to 2000 median Arctic sea-ice extent for each month (http://www.ncdc.noaa.gov/snow-and-ice/). The coloured crosses represent the positions of measured CO profiles shown in Figs. 7 and 8.

Fig. 9a). This case shows a better sensitivity close to the surface (and higher DOFS) compared to the two previous examples over sea ice. Except on first level, the IASI and in situ smoothed profiles are quite similar (difference below 20 ppbv). The last example (case (d)) was measured during the take-off of the ATR-42 in Sweden on 31 March (see Fig. 9a). IASI had problems detecting high $\mathrm{CO}$ signatures measured by the aircraft between the surface to $6 \mathrm{~km}$ probably due to the snow covering the land area (see data from http://www.ncdc.noaa.gov/snow-and-ice/), and low thermal contrast (see the AK plot) $(|\Delta T| \sim 8.5 \mathrm{~K})$. Another explanation could be the collocation. Only one IASI collocated pixel was found and it was almost 50 min before the take-off so it is likely that IASI missed this plume. The difference between the smoothed in situ and IASI values is around 50 to $60 \mathrm{ppbv}$ in altitude range of the plume.
Overall in spring, retrievals over sea resolve better the vertical distribution than over sea ice or snow. The lack of vertical sensitivity and collocation issues were found to be the main reasons influencing plume detection in the IASI data.

\subsubsection{Summer cases}

A profile observed over Hudson Bay on 5 July shows that the DC- 8 measured high CO concentrations between $5-8 \mathrm{~km}$ (see Fig. 8a). IASI was not able to locate precisely this signature, but still captured an enhancement between 4 and $14 \mathrm{~km}$. The smoothed in situ profile clearly illustrates the lack of vertical resolution of the instrument resulting in a broad enhancement in the mid-troposphere. IASI overestimates the CO concentration compared to the in situ smoothed profile with a maximum mixing ratio at $10 \mathrm{~km}$ compared to $6 \mathrm{~km}$ in the in situ profile. However, the ACE climatology is low 
in this case. Tests using higher values for the climatology in the UTLS (Upper Troposphere Lower Stratosphere) results in the smoothed in situ profile becoming closer to the IASI profile suggesting that there could have been enhanced $\mathrm{CO}$ concentrations at this time. Also note that the presence of sea ice in this area in spite of the season (see Fig. 9b) could explain the problem of retrieval with the limited vertical sensitivity. Moreover, the AK has higher values for the two first levels but many rows of the AK matrix are negative at the surface making difficult the retrieval at these altitudes. This explains that the in situ smoothed profile is lower than the a priori below $3 \mathrm{~km}$. Figure $8 \mathrm{~b}$ shows a profile observed over a fire burning region in Siberia during the landing of the Antonov-30 in July 2008 (Fig. 9b). As in the case of Siberian plume transport over Alaska in spring (Fig. 7b), the retrieval smoothes out enhanced $\mathrm{CO}$ at $1 \mathrm{~km}$ and $3 \mathrm{~km}$ due to limited sensitivity for the levels below $3 \mathrm{~km}$. This limited sensitivity is probably due to low thermal contrast between the surface and the first layers of atmosphere corresponding to the altitude of the biomass burning plume $(|\Delta T| \sim 1.0 \mathrm{~K})$. This result in differences ranging from 17 to $113 \mathrm{ppbv}$ below $4.5 \mathrm{~km}$ between the IASI and smoothed in situ profiles. Above $7 \mathrm{~km}$, (in the ACE-FTS climatology part) this difference is around $10 \mathrm{ppbv}$. Case (c) was measured during an ATR-42 take-off in Greenland on 10 July. Both IASI and the aircraft observed clean air with 8 IASI pixels found at almost the same time as the take-off. The difference between the smoothed in situ and IASI varies from 1 to $11 \mathrm{ppbv}$ between $8.5 \mathrm{~km}$ and $0.5 \mathrm{~km}$, respectively. In this case, and considering the size of the IASI footprint, it appears that the IASI data was collected over snow-free land even though the Greenland ice sheet is situated about $100 \mathrm{~km}$ inland.

\subsubsection{Summary}

In summary, the lack of vertical sensitivity was found to be the main detrimental factor for plume detection in the IASI data. Surface type also has a major impact on the quality of the retrieval. Retrieval examples over snow in spring provided similar results as over sea ice. Overall, IASI has better vertical resolution over land, particularly in summer, than over the sea due to higher thermal contrast (Clerbaux et al., 2009). The vertical sensitivity is higher over land than over snow or sea ice. In these examples, the DOFS varied with season. It was around 1 in spring with a maximum of sensitivity between 2 and $10 \mathrm{~km}$, and reached 1.7 in summer for the Antonov-30 flight case with a peak of sensitivity at 1 to $8 \mathrm{~km}$, and a second peak at $10-13 \mathrm{~km}$. The limited vertical sensitivity smoothed out most of pollution plumes but the application of the IASI AKs to the in situ measurements improves the agreement.

\subsection{Results: statistical comparison of whole dataset}

\subsubsection{Comparison by aircraft}

All IASI and smoothed in situ profiles were averaged by season and by aircraft. We chose to compare the IASI retrievals by aircraft because, as explained in Sect. 3, the aircraft did not fly in the same regions or at the same time of year. Therefore, aircraft measured very different types of air mass ranging from flights over boreal fire regions and in air masses downwind of anthropogenic emission regions. Figures 10 and 11 show the comparison between IASI data and averages of the aircraft observations from different spring and summer campaigns, respectively. The number of observations varies according to the aircraft from between 5 and 32 in spring and 8 and 22 in summer. In spring, the mean smoothed in situ profiles are higher than mean IASI profiles above $6 \mathrm{~km}$ which is generally where the climatology part applied. The difference between both profiles reaches $\sim 10 \mathrm{ppbv}$ (17\% maximum) close to $10 \mathrm{~km}$ for the WP-3D and the ATR-42. This difference is similar to the $15 \%$ bias found between ACEFTS and MOZAIC in Clerbaux et al. (2008). For the DC8 , the smoothed in situ $\mathrm{CO}$ is always higher than IASI by only a few ppbv ( $\sim 3-4$ ppbv) and for the P-3B, both profiles are relatively similar up to $6 \mathrm{~km}$. In summer, for each aircraft datasets, IASI CO is higher than smoothed in situ CO below $8 \mathrm{~km}$ altitude where mainly in situ aircraft data was used. This bias is found for all polluted cases. Moreover, with the DC-8 and P-3B is the smoothed in situ CO higher than IASI CO at each level. The bias between the ATR-42 and the Falcon-20, mentioned in Sect. 3.1, is not found in this kind of comparison due to the smoothing with the IASI AK. The CO in situ profiles over Greenland from the ATR-42 and the Falcon-20 are quite similar. Due to the lack of IASI vertical sensitivity at the lowest altitudes, maximum differences are found at the surface (120 ppbv with the P-3B and 20-30 ppbv with the other four aircraft). Nevertheless, the relative difference is always below $20 \%$ and in line to similar validation studies using MOPITT (Emmons et al., 2007) and TES (Lopez et al., 2008) at mid-latitudes. This seasonal difference close to the surface is correlated to the IASI increased surface sensitivity in summer. The DOFS varies between 1.0 and 1.10 in spring with a maximum of sensitivity between 2 and $10 \mathrm{~km}$, and in summer between 1.45 and 1.55 with generally peak sensitivity at $2-8 \mathrm{~km}$, and often a second region of enhanced sensitivity at 9-12 km (not shown).

This comparison was also performed for total columns with average values summarized in Table 3 for the spring campaigns, and Table 4 for the summer campaigns. The mean total columns from IASI and estimated from the smoothed in situ profiles are in good agreement with an absolute value of relative differences ranging from $1.4 \%$ to $5.2 \%$ in spring with the WP-3D and the DC-8, respectively, and ranging from 5 to $10 \%$ in summer. These results are consistent with previous validation studies (e.g. Emmons et al., 

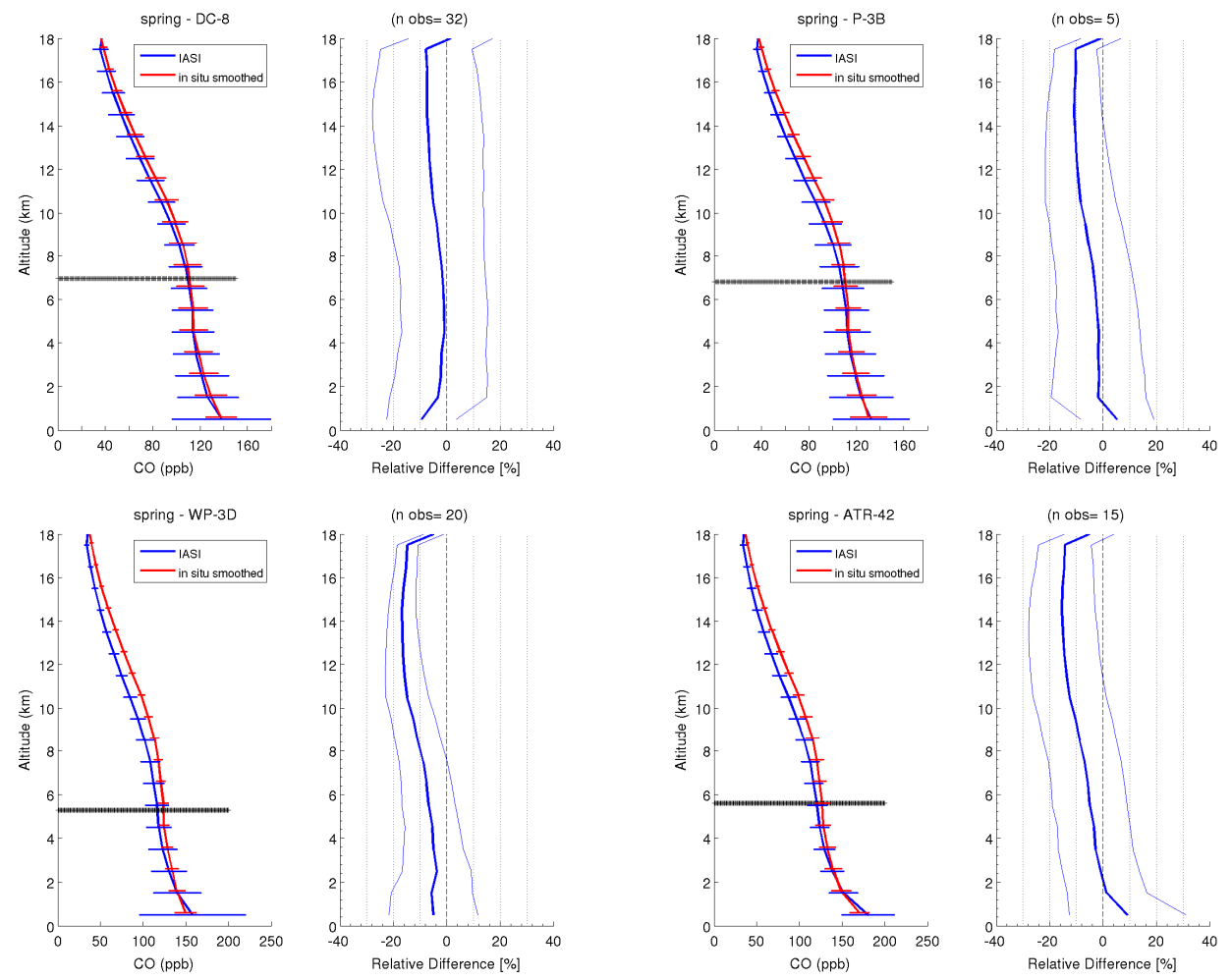

Fig. 10. Average IASI CO profiles (blue line) and smoothed in situ profiles (red line) in ppbv for each spring aircraft campaigns (left panel) and the relative difference (\%) as given in Table 3 (thick blue line) and standard deviation (thin blue lines). The smoothed in situ profiles are the in situ aircraft measurements completed with the ACE-FTS climatology and convolved with IASI AK (see text for details). The horizontal black line represents the mean position of the maximum altitude reached by each particular aircraft. Errors bars represent the variability of measurements.

Table 3. Average IASI and in situ smoothed CO total columns, standard deviations and relative differences calculated as followed: [((IASI-in situ $) \times 2) /($ IASI+in situ $)] \times 100$ for each spring campaign.

\begin{tabular}{lcccc}
\hline $\begin{array}{l}\text { CO Total Column } \\
\left(10^{18} \text { molecules } / \mathrm{cm}^{2}\right)\end{array}$ & DC-8 & P-3B & ATR-42 & WP-3D \\
\hline IASI & $2.22 \pm 0.32$ & $2.16 \pm 0.38$ & $2.45 \pm 0.28$ & $2.25 \pm 0.30$ \\
smoothed in situ* & $2.19 \pm 0.33$ & $2.15 \pm 0.17$ & $2.56 \pm 0.19$ & $2.37 \pm 0.14$ \\
relative difference $(\%)$ & 1.36 & 0.46 & -4.39 & -5.19 \\
\hline
\end{tabular}

* See text for details.

Table 4. As Table 3 for each summer campaign.

\begin{tabular}{lccccc}
\hline $\begin{array}{l}\text { CO Total Column } \\
\left(10^{18} \text { molecules } / \mathrm{cm}^{2}\right)\end{array}$ & DC-8 & P-3B & ATR-42 & Falcon-20 & Antonov-30 \\
\hline IASI & $2.15 \pm 0.54$ & $2.51 \pm 0.74$ & $1.72 \pm 0.25$ & $1.88 \pm 0.38$ & $1.95 \pm 0.33$ \\
smoothed in situ* & $1.93 \pm 0.34$ & $2.26 \pm 0.53$ & $1.63 \pm 0.26$ & $1.74 \pm 0.28$ & $1.82 \pm 0.17$ \\
relative difference $(\%)$ & 10.78 & 10.48 & 5.37 & 7.73 & 6.90 \\
\hline
\end{tabular}

* See text for details 

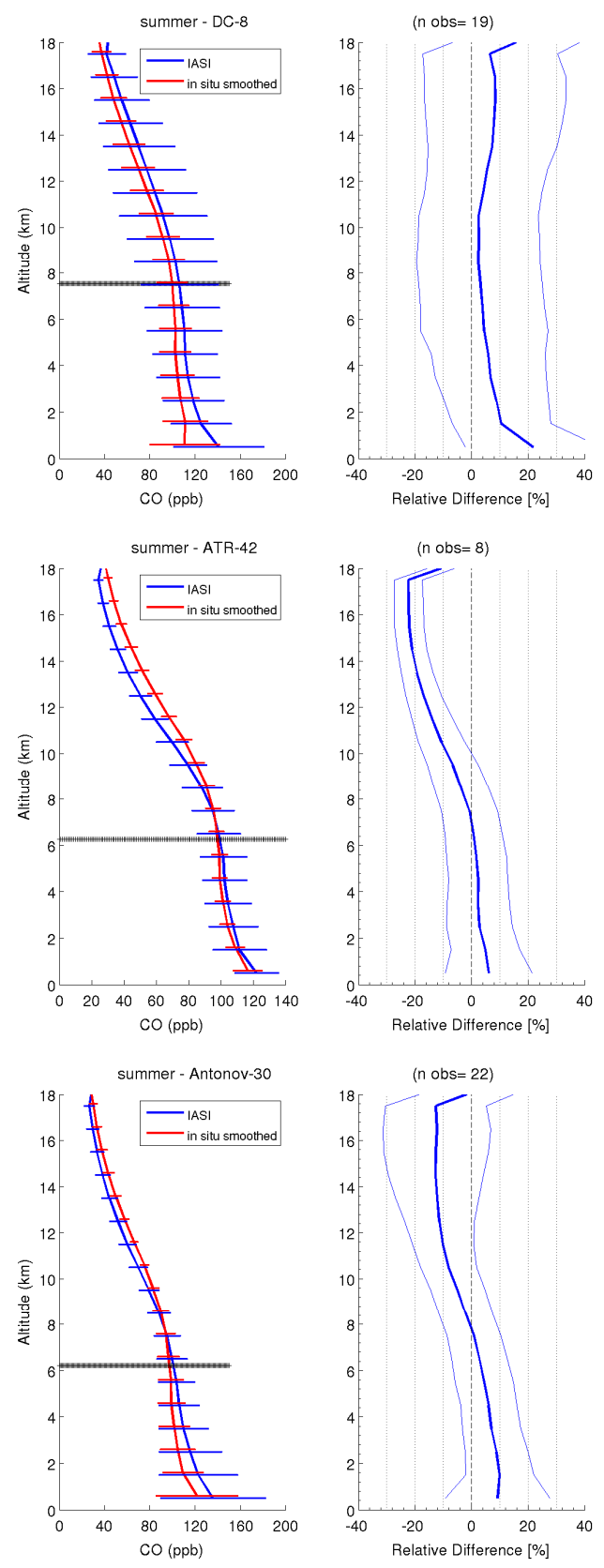

Fig. 11. Same as Fig. 10 for summer campaigns.

2007) and show that for low DOFS, the differences for total columns between IASI and the smoothed in situ measurements are low. For each summer case, the smoothed in situ CO total column is lower than IASI CO total column; this also applies to two aircraft (DC-8 and P-3B) in spring. Figure 12 shows the correlation between all $\mathrm{CO}$ total column data. In both seasons the lowest correlation coefficient, $r$, is obtained in the comparison with the ATR-42 data with $r=0.15$ in spring and $r=0.26$ in summer. In spring, the correlation coefficient reaches 0.74 with the P-3B but it should be noted that only 5 profiles were available. For the other
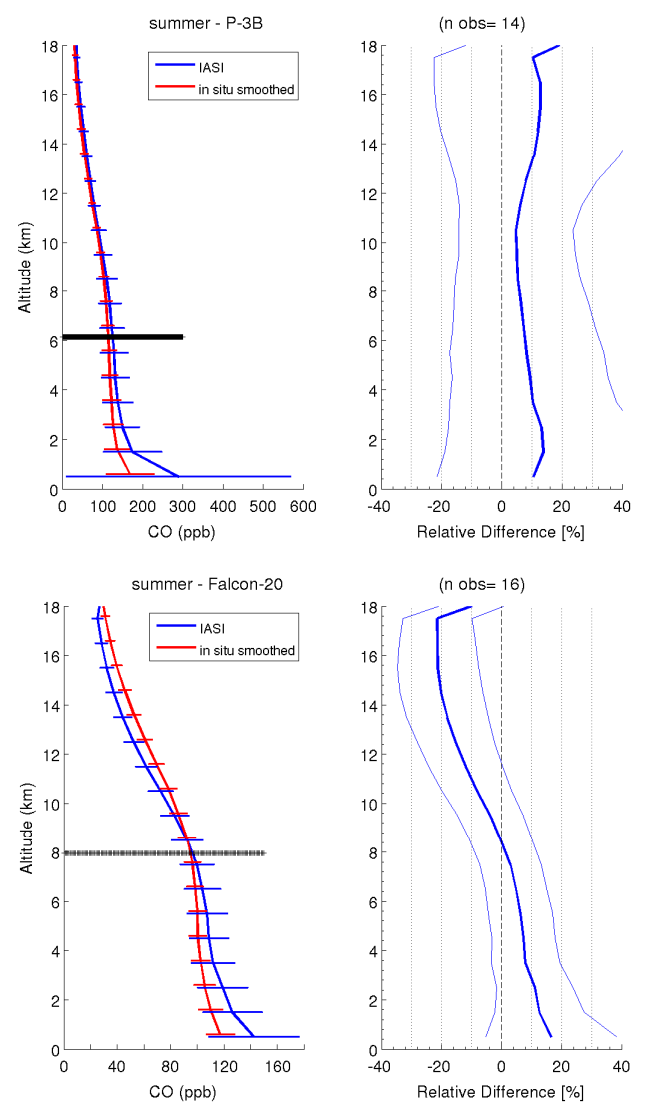

aircraft the correlation coefficient is 0.21 and 0.58 for DC-8 and WP-3D, respectively. In summer, the highest correlation $(r=0.84)$ is found between IASI and the DLR Falcon data using 16 profiles and ranges between 0.50 and 0.60 for the other aircraft.

Limiting the comparison to partial columns, comparing thereby the in situ part and not a combination of in situ and climatology, improves the correlations in the 0 to $5 \mathrm{~km}$ layer, and varies between aircraft from 0.47 to 0.77 in spring and from 0.66 to 0.88 in summer (see Fig. 12). In both seasons, the correlations with the ATR-42, which flew to the lowest 

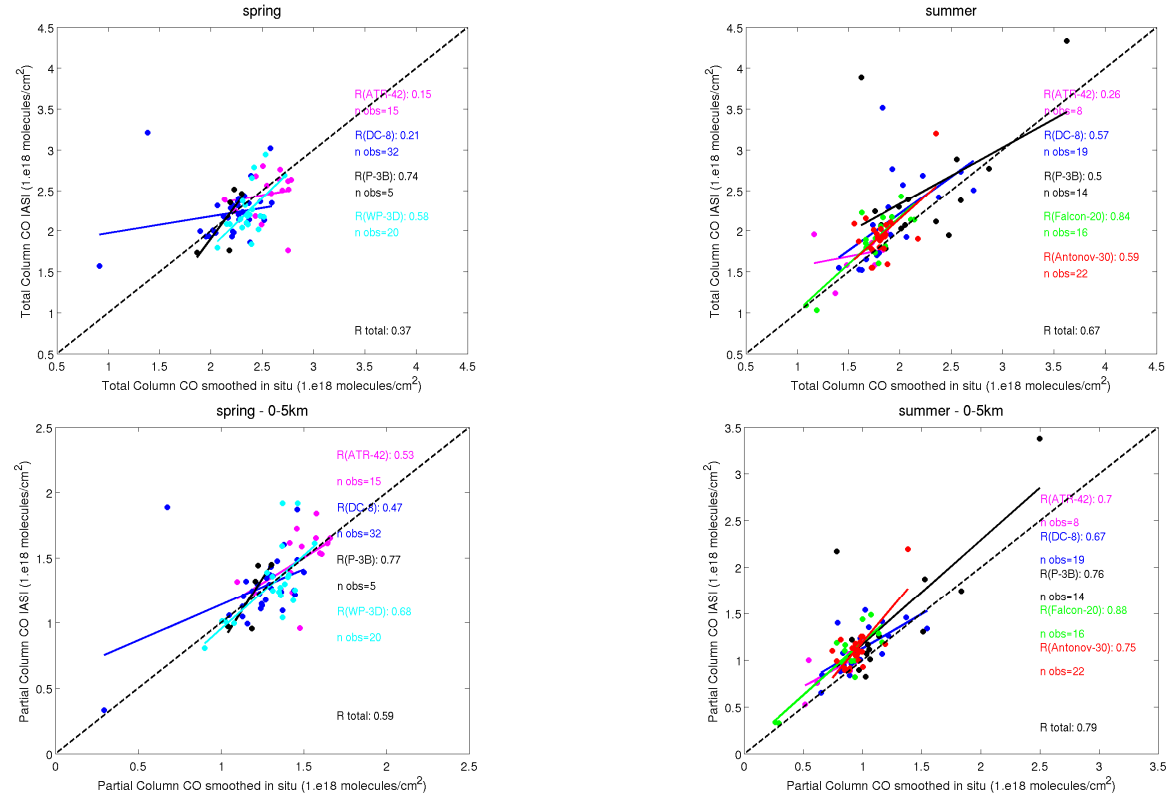

Fig. 12. Scatter plots of IASI and smoothed in situ CO total columns (top) and 0-5 km partial columns (bottom) for the spring (left panel) and the summer (right panel) campaigns. The coloured lines represent the linear regression between data points for each aircraft: ATR-42 (magenta), DC-8 (blue), P-3B (black), WP-3D (cyan), Falcon-20 (green), and Antonov-30 (red). The black dotted line, of unity slope, is shown for reference.

maximum altitudes (up to 6-7 km), are the most improved giving 0.53 in spring and 0.70 in summer. In spring, the IASI collocated profiles with the ATR-42 have the higher sensitivity close to surface. These two factors highlight the importance of a good climatology to complete the profile. Correlations between IASI and the combined dataset using all the aircraft data were also computed. In this case, differences between aircraft measurements and sampling of different air masses need to be kept in mind. The overall correlations are 0.37 in spring and 0.67 in summer and improve to 0.59 in spring and 0.79 in summer when only considering partial columns.

Moreover, these correlations also show, for total columns as well as for partial columns, that when the correlation is higher than 0.5 , IASI values are generally lower than the smoothed in situ values in spring and the inverse in summer.

Overall, this evaluation shows in the spring months maximum differences above $6 \mathrm{~km}$ where the ACE climatology has been used. This results in differences in the total columns varying between $1.4 \%$ and $5.20 \%$ (absolute values) according to aircraft. In summer IASI is always higher than smoothed in situ vertical profiles (20\%) leading to column differences of up to reaching $11 \%$ but correlations are better due to better IASI performance over the land. Again, for the low flying aircraft results are improved when comparing just to partial columns.

\subsubsection{Impact of surface type}

Overall, the DOFS were around 1 in spring whatever surface types and 1.6 over land, and 1.3 over the ocean in summer. This difference is related to a better thermal contrast in the radiance spectra measurements over land in summer where the diurnal surface temperature contrast is more intense than over sea due to the limited heat water capacity (Clerbaux et al., 2009). In spring the maximum sensitivity is found between 2 and $10 \mathrm{~km}$ for all surfaces. In summer there are two peaks: between $1-8 \mathrm{~km}$ and $8-12 \mathrm{~km}$ over land, and between $1-3 \mathrm{~km}$ and $4-11 \mathrm{~km}$ over the sea (not shown).

A study was performed to evaluate the impact of surface type on IASI CO measurements. All the profiles (and corresponding total columns) were averaged according to season, by aircraft, and then separated by sea and land surface type. It should be noted that during the spring campaigns, the same number of observations were performed over the land and sea (36 each) whereas in summer more profiles were obtained over the land (68) with only 11 over the sea. Moreover, in spring most profiles were taken over snow or frozen sea.

In spring, over both surface types, the maximum difference between smoothed in situ and the IASI profiles is close to $10 \%$. In spring, over land (Fig. 13a), IASI is similar or slightly higher than smoothed in situ measurements below $6 \mathrm{~km}$ while over the sea (Fig. 13b) it is lower by a few ppbv. In summer, IASI is higher than the smoothed in situ below $8.5 \mathrm{~km}$ over land and sea. Over land this difference varies from $0.2 \%(8.5 \mathrm{~km})$ to $16 \%(0.5 \mathrm{~km})$ (Fig. 13c) whereas over 

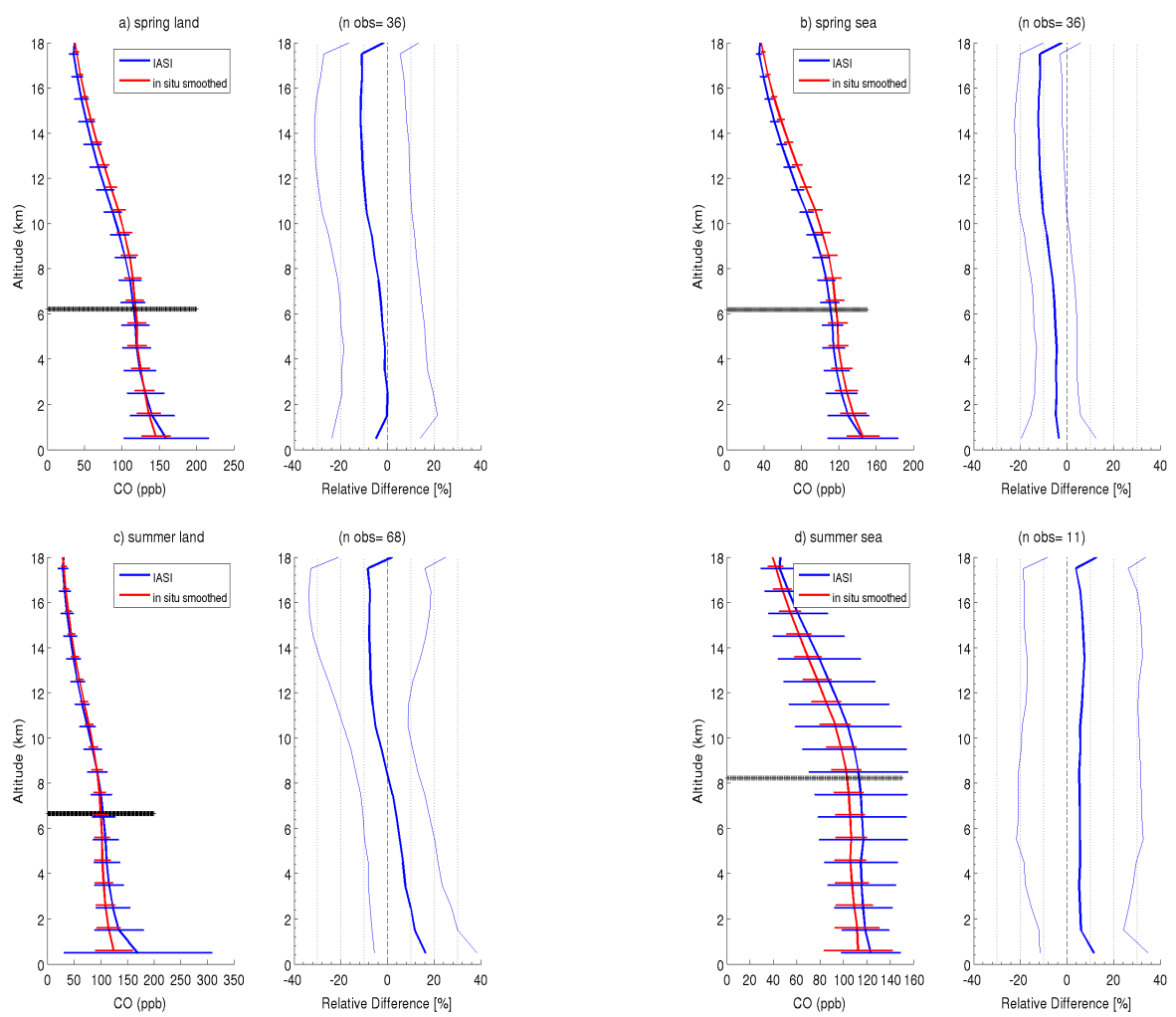

Fig. 13. Average IASI CO profiles (blue line) and smoothed in situ profiles (red line) in ppbv for each season (spring in top panels and summer in bottom panels), over land (a and $\mathbf{c}$ ) and sea (b and d). Relative differences (see Table 5) (thick blue line) and standard deviation (thin blue lines) are also plotted as a function of altitude. The horizontal black line represents the mean position of the maximum altitude reached by each particular aircraft. Errors bars represent the variability of measurements.

the sea (Fig. 13d), IASI CO is about $10 \mathrm{ppbv}$ (maximum $11 \%$ ) higher than smoothed in situ $\mathrm{CO}$ at all altitudes.

When comparing IASI CO total columns and the corresponding smoothed in situ data, a good correlation is found over sea in spring (0.73) and over land in summer (0.69). Worse agreements are found in spring over the land (correlation 0.16) and over the sea in summer (0.33). Whatever the surface type, in spring, the mean IASI total column is lower than the corresponding smoothed in situ total columns. The opposite is found in summer (Table 5) with a maximum difference of $12 \%$. The comparison using just partial columns $(0-5 \mathrm{~km})$ again improves the correlations with 0.48 over the land and 0.78 over the sea for spring and with 0.81 over the land and 0.51 over the sea in summer (not shown).

Over both surface types, as the comparison by aircraft, we still observe a difference of $10 \%$ in spring between profiles. And IASI still has higher values than the smoothed in situ values below $8.5 \mathrm{~km}$ in summer (maximum $16 \%$ ) and for total columns (maximum 12\%).

\section{Further insights into Arctic CO distributions}

\subsection{Spring and summer total columns}

Figure 5 shows the average total CO columns for the month of April and July in 2008. It highlights the seasonal cycle of $\mathrm{CO}$ with higher concentrations in spring due to its longer lifetime following accumulation during the winter, as well as the main anthropogenic emission regions over Asia, North America and Europe. Boreal fire regions can be seen in spring over Siberia and over Siberia and Canada in summer. Evidence for transport of enhanced $\mathrm{CO}$ downwind of continental regions can also be seen.

During April 2008, pollution was transported from agricultural fires in eastern Europe/western Russia, boreal fires in Siberia and from anthropogenic source regions in Asia across the high Arctic Ocean. European pollution was also transported into northern Scandinavia. Plumes from Asia and Europe were observed by the ATR-42 (Adam de Villiers et al., 2010) and some across to Alaska and northern Canada (Warneke et al., 2009). Siberian burning plumes were transported to Alaska by cyclonic activity near Lake Baikal and over the northern Pacific (Fuelberg et al., 2010). An example of the kind of measurements collected during spring is 
Table 5. Average IASI and in situ smoothed CO total columns, standard deviations and relative differences calculated as followed: [((IASIinsitu $) \times 2$ )/(IASI+insitu) $\times 100$; for each season, according to surface type.

\begin{tabular}{lccccc}
\hline \multirow{2}{*}{ CO Total Column $\left(10^{18}\right.$ molecules $\left./ \mathrm{cm}^{2}\right)$} & \multicolumn{2}{c}{ spring } & & \multicolumn{2}{c}{ summer } \\
\cline { 2 - 3 } \cline { 5 - 6 } & land & sea & & land & sea \\
\hline IASI & $2.24 \pm 0.37$ & $2.31 \pm 0.27$ & & $2.02 \pm 0.52$ & $2.31 \pm 0.54$ \\
smoothed in situ* & $2.26 \pm 0.33$ & $2.37 \pm 0.23$ & & $1.87 \pm 0.39$ & $2.04 \pm 0.26$ \\
relative difference (\%) & -0.89 & -2.56 & & 7.71 & 12.41 \\
\hline
\end{tabular}

* See text for details.

a)

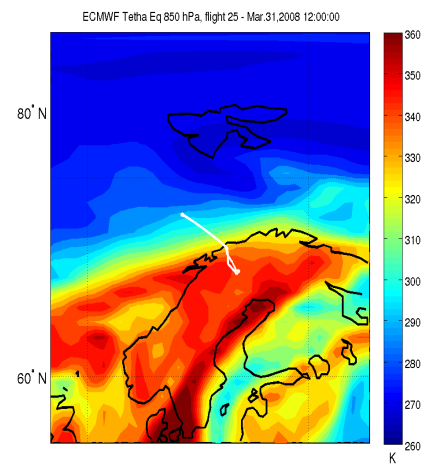

b)

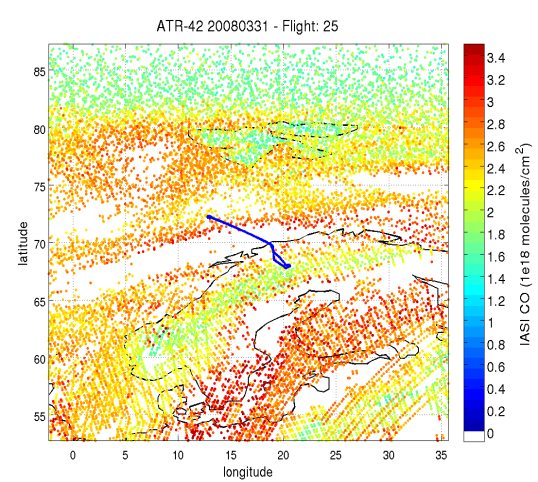

Fig. 14. ECMWF potential equivalent temperature at $850 \mathrm{hPa}$ above Scandinavia (a) and daytime IASI CO total column map (b) on 31 March 2008. On both maps, the ATR-42 flight track is also shown (white line in panel a and blue line in panel b).

shown in Fig. 14 when, as part of POLARCAT-France, measurements were made north of Scandinavia. In this example, on 31 March 2008, IASI measurements show strong gradients over this region (Fig. 14b). They correspond to the position of the polar front, which blocked European pollution to the south (Fig. 14a). Note that since clouds were associated with the front and only clear-sky measurements are analysed with IASI, there is a lack of IASI observations over this area. Moreover, the lower total column values over Spitsbergen show the impact of topography and snow on the retrieval, or sea ice up to $82^{\circ} \mathrm{N}$. This shows the impact of low sensitivity over sea ice or snow as observed with cases in Fig. 7.

Summer meteorological conditions were different and, in general, weather systems were less intense during, for example, the ARCTAS-B period compared to the spring ( $\mathrm{Fu}-$ elberg et al., 2010). During the aircraft campaigns based in western Greenland in July 2008 rather clean air masses were sampled at the beginning of the month. Then, a series of low-pressure systems transported North American anthropogenic pollution and Canadian biomass burning plumes over southern Greenland. This was followed by air masses arriving from the north transporting pollution from Siberian boreal fires or Asia anthropogenic emission regions. The ARCTAS-B flights sampled Canadian boreal fire plumes (Jacob et al., 2010) whereas the YAK flights sampled Siberian fires (Paris et al., 2009). The daily coverage of IASI allows the detection of the CO long-range transport events. An example is illustrated in Fig. 15 which shows snapshots of four daily total column maps during July 2008. On 2 July 2008 (Fig. 15a), CO source regions can be seen over Asia and North America. CO plumes from Asia were transported out of the continent and were divided into two branches on 7 July (Fig. 15b), one part crossing the North Pole and the second reaching the western coast of North America. In addition, North American plumes were transported across the North Atlantic towards Greenland by frontal systems. By the 9 July (Fig. 15c), the Asian plume was transported directly over the Arctic to Greenland and the North American plumes either reached western Europe or were transported further north over Greenland. The case of Asian plume transport over the Arctic to Greenland is discussed in detail in Soderman et al. (2010). On 11 July (Fig. 15d), aged plumes can still be seen over Greenland although they were diluted due to mixing with cleaner air masses. Also due to higher orography over Greenland, $\mathrm{CO}$ enhancements (plumes) are less evident in the IASI data. 
a)

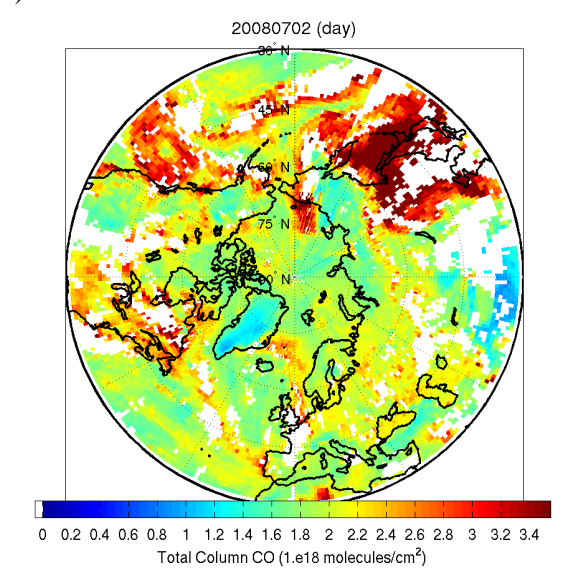

c)

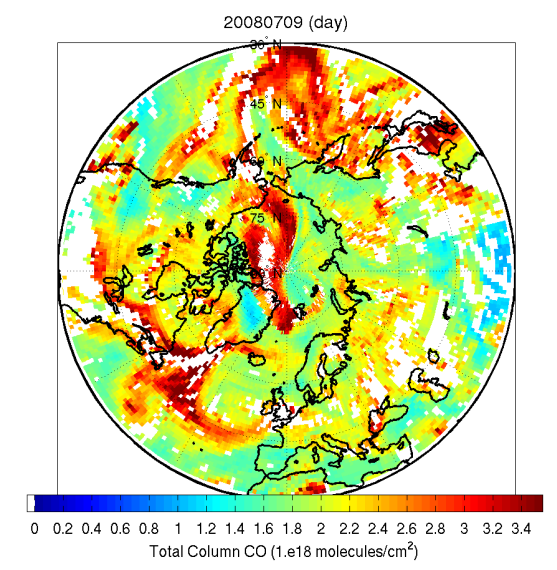

b)

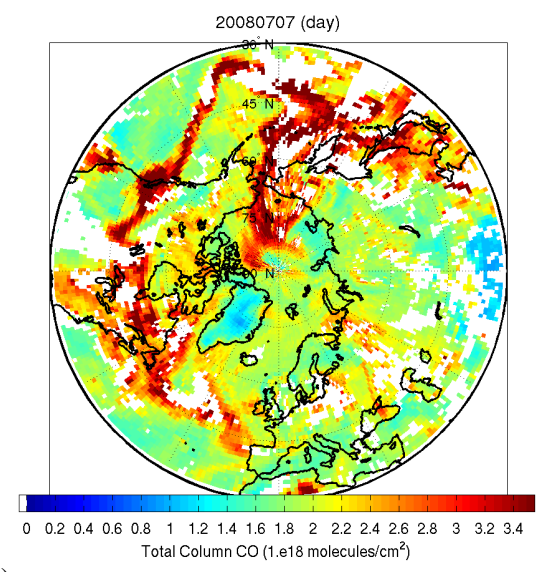

d)

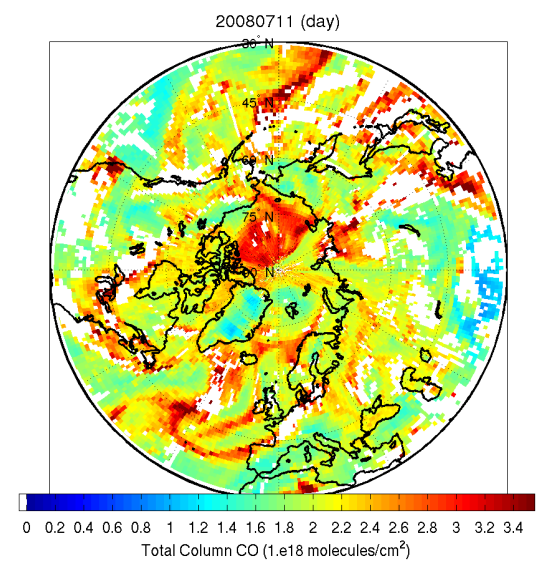

Fig. 15. Daily IASI CO total column maps on a $1^{\circ} \times 1^{\circ}$ grid for the 2 July (a), 7 July (b), 9 July (c) and 11 July (d) 2008.

\subsection{Spatial plume distributions seen by IASI}

In this section, we illustrate the ability of IASI to observe $\mathrm{CO}$ plumes at high spatial resolution given the spatial footprint of the instrument. We also show direct comparisons between the aircraft data and IASI data along the aircraft flight tracks, i.e. without accounting for the IASI limited vertical sensitivity. Since we show comparisons along horizontal and vertical legs of flights we have not applied the IASI AK in these cases. This qualitative approach illustrates the ability of IASI to detect different plumes at different altitudes and also shows the influence of surface type on column retrievals.

\subsubsection{Selected spring flights}

Figure 16 shows three examples of $\mathrm{CO}$ distributions observed by the aircraft during spring flights of the DC- 8 , the ATR-42 and the WP-3D, along with the corresponding IASI retrievals highlighting the snow-sea ice/sea differences discussed in Sect. 4.4.1. The number of IASI collocation was 162, 29 and 44, respectively. On 9 April, the DC8 flew across the North Pole from Iqaluit (eastern coast of
Canada) to Fairbanks (Alaska). IASI detected an enhancement due European pollution (see http://www.espo.nasa.gov/ arctas/docs/flight/2008-4-9_dc8_report.pdf) at the end of the flight ("plume a") above the land between the ground and $2 \mathrm{~km}$. However, the retrieved concentrations are lower than the in situ measurement by about $40 \mathrm{ppbv}$. As discussed in Sect. 4.4.1 and illustrated in Fig. 7a, the main part of the flight was above the sea ice or above the snow and most of the IASI CO data have a DOFS around 1.0 and thus a lack of sensitivity at low altitudes.

On 10 April, IASI observed another plume (CO $\sim 160$ ppbv measured in situ) above the Arctic Ocean close to the surface between 11:40 and 12:30 UTC. As shown in Fig. 7c (corresponding to the second profile during this flight) the DOFS was around 1.10 in this region. Note that IASI did not detect a CO signature in the first hour of this flight. Snow covered land can explain this lack of vertical sensitivity. The total IASI columns for this day clearly show plumes that have been transported from Asia which, as discussed in detail by Adam de Villiers et al. (2010), were mixtures of plumes originating from Asian pollution and dust as well as Siberian forest fire plumes. The comparison with the 31 March (Fig. 14) 

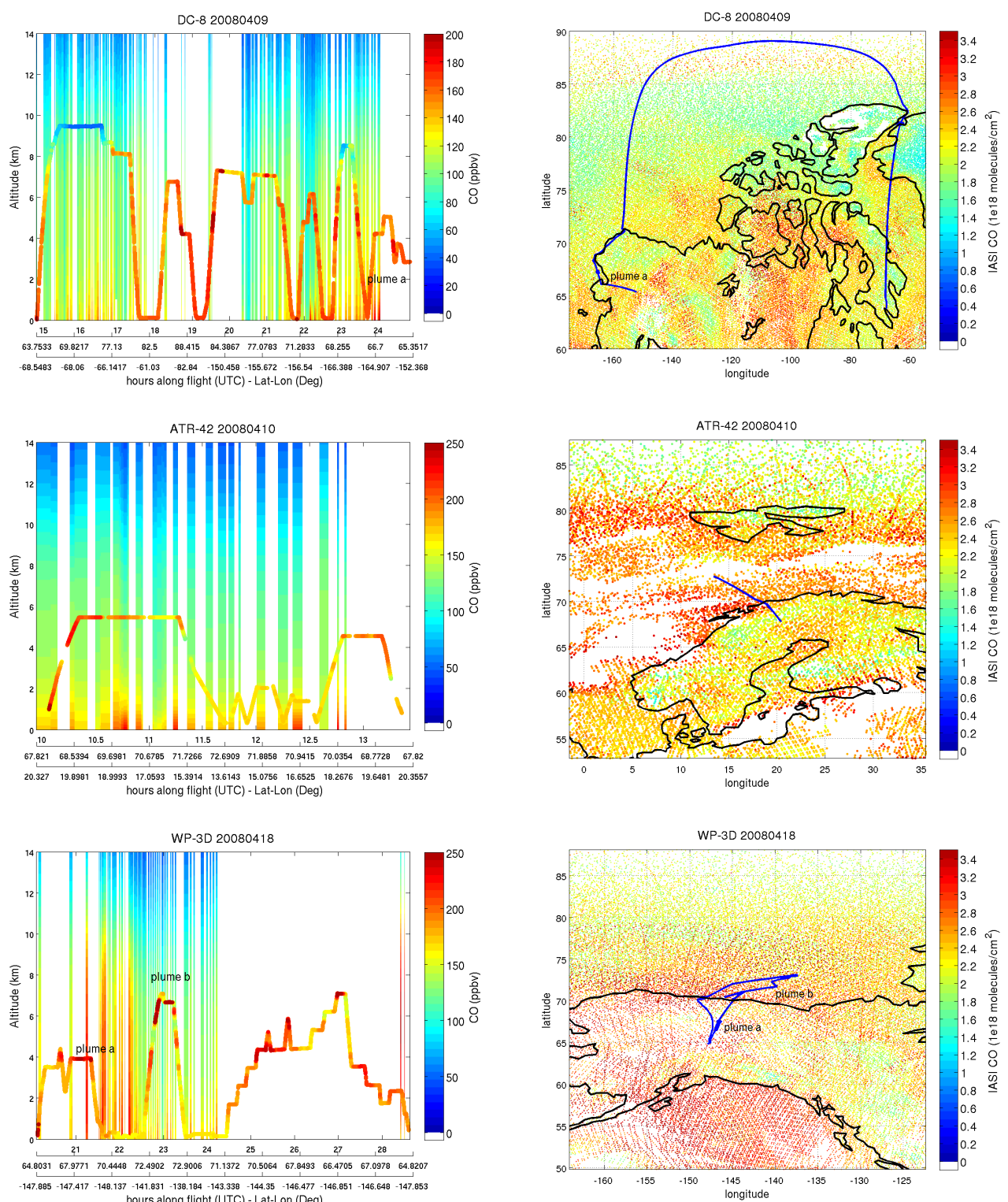

Fig. 16. Left: cross-sections representing the CO mixing ratio (in ppbv) measurements along the DC-8 flight on 9 April (top), the ATR-42 flight on 10 April (middle), and the WP-3D flight on 18 April 2008 (bottom), compared with IASI CO distributions with a criterion of $\left[ \pm 0.2^{\circ} ; \pm 1 \mathrm{~h}\right]$. In situ CO is plotted as a function of altitude versus UTC time along each flight. Corresponding aircraft positions in latitude and longitude are also given. Right: day-time IASI CO column observations in molecules $/ \mathrm{cm}^{2}$ in the region of the flights (track shown in blue).

shows the evolution of type of pollution, with an influence of European pollution during first days of the POLARCATFrance campaign and Asian pollution at the end.

On 18 April, the WP-3D sampled a plume originating from Kazakhstan agricultural fires (aged 7-9 days) and a forest fire plume from Lake Baikal, Siberia (aged 45 days). These plumes, identified in Fig. 16c as "plume a" and "plume b", are described in detail by Warneke et al. (2009). IASI observed a signature of the agricultural fire plumes around $4 \mathrm{~km}$ ("plume a") corresponding to about
215 ppbv compared to 223 ppbv observed by the NOAA P3 aircraft (maximum around $250 \mathrm{ppbv}$ ). IASI did not observe Siberian forest fire signature during the ascent and the descent around 23:00 UTC (plume b), due to the lack of sensitivity (DOFS 1.0 ) over frozen sea at this time of year (see Fig. 7b). Nevertheless, enhanced $\mathrm{CO}$ was observed over the whole region of the flight as shown in the total column map. 

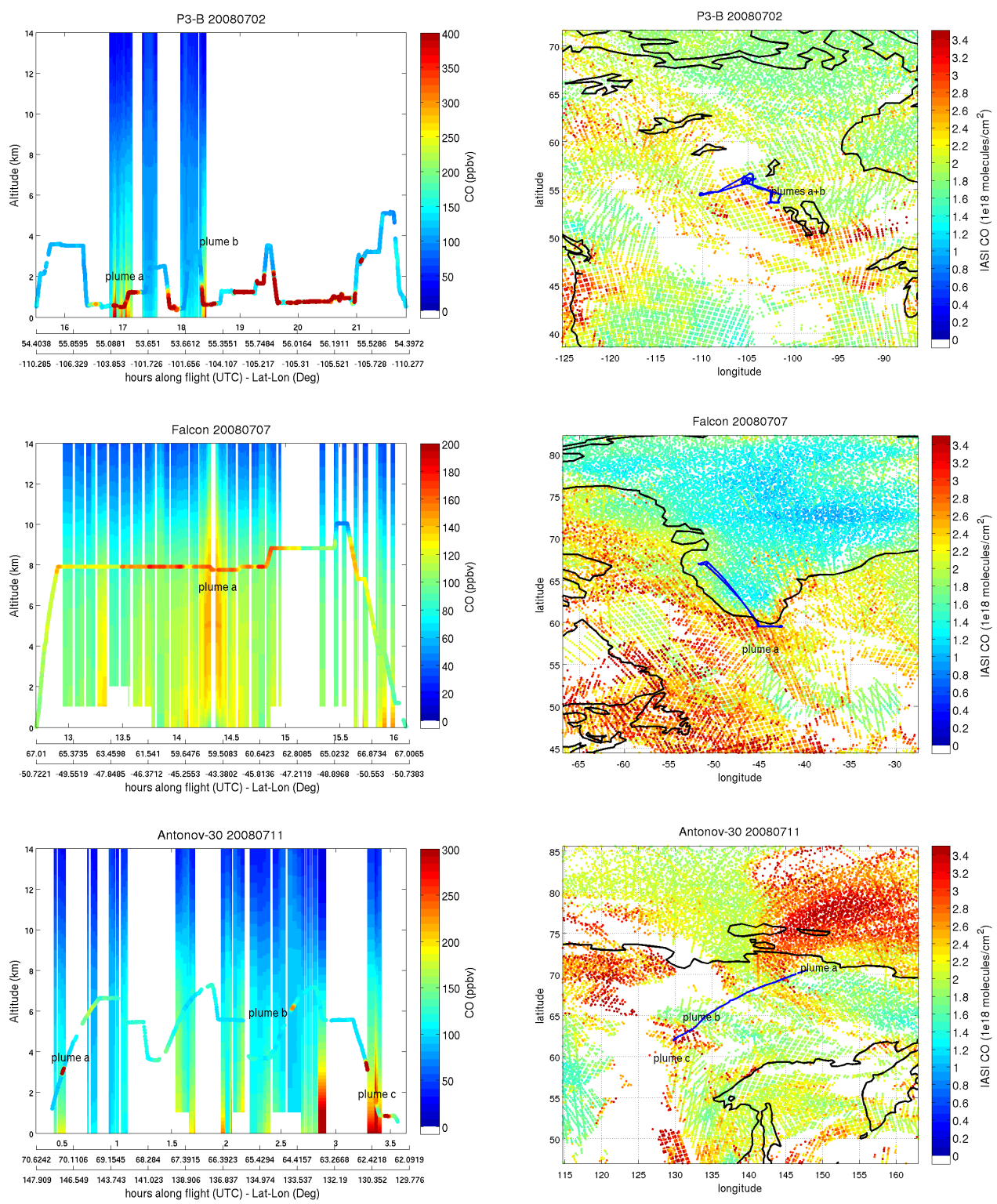

Fig. 17. Same as Fig. 16 for the P-3B flight on 2 July (top), Falcon-20 flight on 7 July (middle) and Antonov-30 flight on 11 July 2008 (bottom).

\subsubsection{Selected summer flights}

Figure 17 shows three examples of summer flights showing IASI's capability to detect plumes of different origins downwind and over emission regions. The total column maps show the data for each flight at higher resolution than in Fig. 15. Along a P-3B flight on 2 July very close to Canadian boreal fires (see map in Fig. 17), relatively good agreement is found between IASI and in situ CO measurements in the boundary layer with large CO signatures at 17:00 UTC and 18.30 UTC, labelled "plume a" and "plume b", respectively. This is despite the fact that only 23 IASI pixels were found in the flight area. For both plumes, the maximum $\mathrm{CO}$ measured by the aircraft was around 1 ppmv. IASI observed lower values compared to the non-corrected aircraft data of around $700 \mathrm{ppbv}$ in "plume a" and $450 \mathrm{ppbv}$ in "plume b". The IASI DOFS are around 1.5 and the sensitivity is highest between 2 and $7 \mathrm{~km}$ (not shown). During this flight, the NASA P-3B flew directly inside boreal forest fire plumes that were also detected by IASI in the south-eastern part of the flight. Two plumes, located around 0.5 to $1.2 \mathrm{~km}$ and 0.6 to $1.8 \mathrm{~km}$, respectively, were observed by IASI below $4 \mathrm{~km}$. Background concentrations were also reasonably well observed after 18:00 UTC. 
On 7 July, the Falcon-20 flew in a mixture of North American forest fire and anthropogenic plumes in southern Greenland (see maps in Fig. 17 and Fig. 15b). A strong gradient is apparent between the plumes over the ocean and the ice sheet in Greenland still showing the problem of topography on total columns values. Fifty-eight IASI collocations were found with a mean DOFS of 1.40 for this flight. The in situ measured $\mathrm{CO}$ was around $160 \mathrm{ppbv}$ and IASI CO observed about 120 ppbv. The DLR Falcon-20 measured a more extensive plume (in latitude) than IASI showing the IASI's difficulties to detect $\mathrm{CO}$ enhancement over the ice sheet.

On 11 July the Antonov-30 sampled forest fires plumes over Siberia during landing ("plume c") (see also discussion in Sect. 4.4.2). This case is also described in detail in Paris et al. (2009). The plume was encountered at low altitudes in the boundary layer very close to the fire source region. IASI detected a signature around $350 \mathrm{ppbv}$ when more than $600 \mathrm{ppbv}$ was measured by the aircraft. In this case, the IASI DOFS was around 1.7 (see Fig. 8b). Two other $\mathrm{CO}$ plumes were also observed by the aircraft during this flight ("plume a" and "plume b") but were not detected by IASI. These plumes were too thin for the satellite instrument vertical sensitivity to be detected. Concentrations in clean background air were also well captured by IASI during the rest of the flight. It means that, in this case, the a priori used in the retrieval is in good agreement with in situ observations. IASI also observed a $\mathrm{CO}$ plume transport further north and $\mathrm{CO}$ emissions over western Siberia (not in the flight area). Overall, IASI achieves better vertical sensitivity in the summer over the Arctic than in the spring, due to a higher thermal contrast, resulting in improved detection of $\mathrm{CO}$ plumes during these hotter months.

\section{Conclusions}

This paper reports a detailed comparison of $\mathrm{CO}$ data obtained from the IASI satellite-borne mission with in situ aircraft measurements measured as part of the POLARCAT project in spring and summer 2008. Aircraft data were collected in different parts of the Arctic in air masses originating from anthropogenic and forest fire emission regions. Data were also collected close to boreal forest fires over Siberia and Canada. IASI was able to detect several fire events as well as high $\mathrm{CO}$ signatures in the boundary layer due to forest fires in July 2008. It also provides high spatial information about CO plume distributions due to its high resolution footprint which can be used to interpret aircraft observations. We illustrated that the detection of high $\mathrm{CO}$ events is more difficult over sea ice and snow because IASI CO retrievals show less sensitivity near the ground for cases associated with low thermal contrast.

For the comparison IASI data were selected using a collocation criterion of $\left[ \pm 0.2^{\circ} ; \pm 1 \mathrm{~h}\right]$ around the flights. Relaxing the collocation criterion did not lead to an improvement in the results due to the fact that air masses of different origin were likely to have been sampled. Aircraft profiles were completed with a seasonal and latitudinal climatology based on ACE-FTS data averaged from 2004 to 2009 above aircraft maximum flight ceilings and convolved with the IASI averaging kernels (called smoothed in situ profiles). Overall, the results presented here show that IASI performs in Arctic as well, or better than other satellite instruments measuring $\mathrm{CO}$ which have been validated at mid-latitudes. In spring differences of $\sim 10 \mathrm{ppbv}$ (maximum 17\%) were found for the profiles and between 1 to $5 \%$ for the total columns. In summer, for all the cases investigated, the difference between profiles can reach $20 \%$ below $8 \mathrm{~km}$. For summertime total columns a $12 \%$ maximum difference was found although this value varies as a function of surface type. Nevertheless, due to a better thermal contrast in summer and thus a better vertical sensitivity, more particularly over land, the correlations for total columns were better in summer from 0.26 to 0.84 against from 0.15 to 0.74 in spring.

In spite of these difficulties, the analysis presented here has shown the capability of IASI to observe long-range transport of $\mathrm{CO}$ into the Arctic and its potential to detect spatial and broad vertical structure of pollutant plumes. This validation work needs to be extended to other latitudes using other aircraft data (e.g. MOZAIC), and to other species (e.g. ozone) retrieved by IASI. Assimilation of IASI CO in global models can be used to quantify pollution export to the Arctic, the budgets of $\mathrm{CO}$ and ozone as well as to better constrain $\mathrm{CO}$ sources.

Acknowledgements. M. Pommier was supported by a grant from CNES (Centre national d'Etudes Spatiales) and by NOVELTIS IASI was developed and built under the responsibility of CNES and flies onboard the MetOp satellite as part of the Eumetsat Polar system. The IASI L1 data are received through the Eumetcast near real time data distribution service. IASI L1 and L2 data are stored in the Ether French atmospheric database (http://ether.ipsl.jussieu.fr). We thank Raphaël Adam de Villiers for his contribution to this work. The research in Belgium was funded by the "Actions de Recherche Concertées" (Communauté Francaise), the Fonds National de la Recherche Scientifique (FRS-FNRS F.4511.08), the Belgian State Federal Office for Scientific, Technical and Cultural Affairs and the European Space Agency (ESA-Prodex C90-327). POLARCAT-France was funded by French ANR, CNES, CNRS-INSU (LEFE-CHAT), IPEV and also EUFAR. POLARCAT-GRACE was funded by DLR. The YAK-AEROSIB campaigns were funded by the CNRS-DRI (France), the French Ministry of Foreign Affairs, CEA (France), POLARCAT France/Norway, RAS (Russia) and RFBR (Russia), and operated in collaboration with IAO-SB-RAS, Tomsk, Russia. The ACE mission is supported primarily by the Canadian Space Agency and the UK Natural Environment Research Council (NERC). The authors are grateful to CNRS-INSU for publication support.

Edited by: P. Monks 


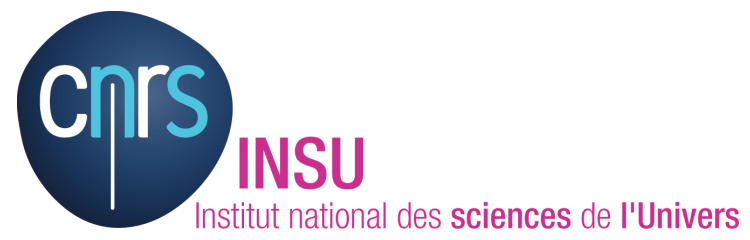

The publication of this article is financed by CNRS-INSU.

\section{References}

de Villiers, R. A., Ancellet, G., Pelon, J., Quennehen, B., Schwarzenboeck, A., Gayet, J. F., and Law, K. S.: Airborne measurements of aerosol optical properties related to early spring transport of mid-latitude sources into the Arctic, Atmos. Chem. Phys., 10, 5011-5030, doi:10.5194/acp-10-5011-2010, 2010.

Ancellet, G., Leclair de Bellevue, J., Mari, C., Nedelec, P., Kukui, A., Borbon, A., and Perros, P.: Effects of regional-scale and convective transports on tropospheric ozone chemistry revealed by aircraft observations during the wet season of the AMMA campaign, Atmos. Chem. Phys., 9, 383-411, doi:10.5194/acp-9-3832009, 2009.

Atlas, E. L., Ridley, B. A., and Cantrell, C. A.: The Tropospheric Ozone Production about the Spring Equinox (TOPSE) Experiment: Introduction, J. Geophys. Res., 108(D4), 8353, doi:10.1029/2002JD003172, 2003.

Badr, O. and Probert, S. D.: Carbon monoxide concentration in the Earth's atmosphere, Appl. Energy, 50(4), 339-372, 1995.

Baehr, J., Schlager, H., Ziereis, H., Stock, P., van Velthoven, P., Busen, R., Ström, J., and Schumann U.: Aircraft observations of $\mathrm{NO}, \mathrm{NO}_{\mathrm{y}}, \mathrm{CO}$, and $\mathrm{O}_{3}$ in the upper troposphere from $60^{\circ} \mathrm{N}$ to $60^{\circ} \mathrm{S}$ - Interhemispheric differences at midlatitudes, Geophys. Res. Lett., 30, 1598, doi:10.1029/2003GL016935, 2003.

Bernath, P. F., McElroy, C. T., Abrams, M. C., Boone, C. D., Butler, M., Camy-Peyret, C., Carleer, M., Clerbaux, C., Coheur, P.-F., Colin, R., DeCola, P., DeMazière, M., Drummond, J. R., Dufour, D., Evans, W. F. J., Fast, H., Fussen, D., Gilbert, K., Jennings, D. E., Llewellyn, E. J., Lowe, R. P., Mahieu, E., McConnell, J. C., McHugh, M., McLeod, S. D., Michaud, R., Midwinter, C., Nassar, R., Nichitiu, F., Nowlan, C., Rinsland, C. P., Rochon, Y. J., Rowlands, N., Semeniuk, K., Simon, P., Skelton, R., Sloan, J. J., Soucy, M.-A., Strong, K., Tremblay, P., Turnbull, D., Walker, K. A., Walkty, I., Wardle, D. A., Wehrle, V., Zander, R., and Zou, J.: Atmospheric Chemistry Experiment (ACE): Mission overview, Geophys. Res. Lett., 32, L15S01, doi:10.1029/2005GL022386, 2005.

Boone, C. D., Nassar, R., Walker, K.A., Rochon, Y., McLeod, S. D., Rinsland, C. P., and Bernath, P. F.: Retrievals for the atmospheric chemistry experiment Fourier-transform spectrometer, Appl. Optics, 44, 7218-7231, 2005.

Boynard, A., Clerbaux, C., Coheur, P.-F., Hurtmans, D., Turquety, S., George, M., Hadji-Lazaro, J., Keim, C., and MeyerArnek, J.: Measurements of total and tropospheric ozone from IASI: comparison with correlative satellite, ground-based and ozonesonde observations, Atmos. Chem. Phys., 9, 6255-6271, doi:10.5194/acp-9-6255-2009, 2009.

Clarisse, L., Coheur, P. F., Prata, A. J., Hurtmans, D., Razavi, A., Phulpin, T., Hadji-Lazaro, J., and Clerbaux, C.: Tracking and quantifying volcanic $\mathrm{SO}_{2}$ with IASI, the September 2007 eruption at Jebel at Tair, Atmos. Chem. Phys., 8, 7723-7734, doi:10.5194/acp-8-7723-2008, 2008.

Clerbaux, C., Coheur, P.-F., Hurtmans, D., Barret, B., Carleer, M., Colin, R., Semeniuk, K., McConnell, J. C., Boone, C., and Bernath, P.: Carbon monoxide distribution from the ACEFTS solar occultation measurements, Geophys. Res. Lett., 32, L16S01, doi:10.1029/2005GL022394, 2005.

Clerbaux, C., George, M., Turquety, S., Walker, K. A., Barret, B., Bernath, P., Boone, C., Borsdorff, T., Cammas, J. P., Catoire, V., Coffey, M., Coheur, P.-F., Deeter, M., De Mazière, M., Drummond, J., Duchatelet, P., Dupuy, E., de Zafra, R., Eddounia, F., Edwards, D. P., Emmons, L., Funke, B., Gille, J., Griffith, D. W. T., Hannigan, J., Hase, F., Höpfner, M., Jones, N., Kagawa, A., Kasai, Y., Kramer, I., Le Flochmoën, E., Livesey, N. J., López-Puertas, M., Luo, M., Mahieu, E., Murtagh, D., Nédélec, P., Pazmino, A., Pumphrey, H., Ricaud, P., Rinsland, C. P., Robert, C., Schneider, M., Senten, C., Stiller, G., Strandberg, A., Strong, K., Sussmann, R., Thouret, V., Urban, J., and Wiacek, A.: CO measurements from the ACE-FTS satellite instrument: data analysis and validation using ground-based, airborne and spaceborne observations, Atmos. Chem. Phys., 8, 2569-2594, doi:10.5194/acp-8-2569-2008, 2008.

Clerbaux, C., Boynard, A., Clarisse, L., George, M., Hadji-Lazaro, J., Herbin, H., Hurtmans, D., Pommier, M., Razavi, A., Turquety, S., Wespes, C., and Coheur, P.-F.: Monitoring of atmospheric composition using the thermal infrared IASI/MetOp sounder, Atmos. Chem. Phys., 9, 6041-6054, doi:10.5194/acp-9-6041-2009, 2009.

Coheur, P.-F., Herbin, H., Clerbaux, C., Hurtmans, D., Wespes, C., Carleer, M., Turquety, S., Rinsland, C. P., Remedios, J., Hauglustaine, D., Boone, C. D., and Bernath, P. F.: ACE-FTS observation of a young biomass burning plume: first reported measurements of $\mathrm{C}_{2} \mathrm{H}_{4}, \mathrm{C}_{3} \mathrm{H}_{6} \mathrm{O}, \mathrm{H}_{2} \mathrm{CO}$ and PAN by infrared occultation from space, Atmos. Chem. Phys., 7, 5437-5446, doi:10.5194/acp-75437-2007, 2007.

Coheur, P.-F., Clarisse, L., Turquety, S., Hurtmans, D., and Clerbaux, C.: IASI measurements of reactive trace species in biomass burning plumes, Atmos. Chem. Phys., 9, 5655-5667, doi:10.5194/acp-9-5655-2009, 2009.

Emmons, L. K., Pfister, G. G., Edwards, D. P., Gille, J. C., Sachse, G., Blake, D., Wofsy, S., Gerbig, C., Matross, D., and Nédélec P.: Measurements of Pollution in the Troposphere (MOPITT) validation exercises during summer 2004 field campaigns over North America, J. Geophys. Res., 112, D12S02, doi:10.1029/2006JD007833, 2007.

Fehsenfeld, F. C., Ancellet, G., Bates, T. S., Goldstein, A. H., Hardesty, R. M., Honrath, R., Law, K. S., Lewis, A. C., Leaitch, R., McKeen, S., Meagher, J., Parrish, D. D., Pszenny, A. A. P., Russell, P. B., Schlager, H., Seinfeld, J., Talbot, R., and Zbinden, R.: International Consortium for Atmospheric Research on Transport and Transformation (ICARTT): North America to EuropeOverview of the 2004 summer field study, J. Geophys. Res., 111, D23S01, doi:10.1029/2006JD007829, 2006.

Fisher, J. A., Jacob, D. J., Purdy, M. T., Kopacz, M., Le Sager, P., Carouge, C., Holmes, C. D., Yantosca, R. M., Batchelor, R. L., Strong, K., Diskin, G. S., Fuelberg, H. E., Holloway, J. S., Hyer, E. J., McMillan, W. W., Warner, J., Streets, D. G., Zhang, Q., Wang, Y., and Wu, S.: Source attribution and interannual variability of Arctic pollution in spring constrained 
by aircraft (ARCTAS, ARCPAC) and satellite (AIRS) observations of carbon monoxide, Atmos. Chem. Phys., 10, 977-996, doi:10.5194/acp-10-977-2010, 2010.

Fuelberg, H. E., Harrigan, D. L., and Sessions, W.: A meteorological overview of the ARCTAS 2008 mission, Atmos. Chem. Phys., 10, 817-842, doi:10.5194/acp-10-817-2010, 2010.

George, M., Clerbaux, C., Hurtmans, D., Turquety, S., Coheur, P.F., Pommier, M., Hadji-Lazaro, J., Edwards, D. P., Worden, H., Luo, M., Rinsland, C., and McMillan, W.: Carbon monoxide distributions from the IASI/METOP mission: evaluation with other space-borne remote sensors, Atmos. Chem. Phys., 9, 8317-8330, doi:10.5194/acp-9-8317-2009, 2009.

Greenaway, K. R.: Experiences with Arctic flying weather, Royal Meteorological Society Canadian Branch, 1950, Toronto, Ontario, Canada.

Harriss, R. C., Wofsy, S. C., Bartlett, D. S., Shipham, M. C., Jacob, D. J., Hoell Jr., J. M., Bendura, R. J., Drewry, J. W., McNeal, R. J., Navarro, R. L., Gidge, R. N., and Rabine, V. E.: The Arctic Boundary Layer Expedition (ABLE 3A): July-August 1988, J. Geophys. Res., 97(D15), 16383-16394, 1992.

Helmig, D., Oltmans, S. J., Morse, T. O., and Dibb, J. E.: What is causing high ozone at Summit, Greenland?, Atmos. Environ., 41, 5031-5043, 2007.

Herbin, H., Hurtmans, D., Clerbaux, C., Clarisse, L., and Coheur, P.-F.: $\mathrm{H}_{2}^{16} \mathrm{O}$ and HDO measurements with IASI/MetOp, Atmos. Chem. Phys., 9, 9433-9447, doi:10.5194/acp-9-9433-2009, 2009.

Holloway, J. S., Jakoubek, R., Parrish, D., Gerbig, C., VolzThomas, A., Schmitgen, S., Fried, A., Wert, B., Henry, B., and Drummond, J.: Airborne intercomparison of vacuum ultraviolet fluorescence and tunable diode laser absorption measurements of tropospheric carbon monoxide, J. Geophys. Res.-Atmos., 105, 24251-24261, 2000.

Jacob, D. J., Crawford, J. H., Maring, H., Clarke, A. D., Dibb, J. E., Emmons, L. K., Ferrare, R. A., Hostetler, C. A., Russell, P. B., Singh, H. B., Thompson, A. M., Shaw, G. E., McCauley, E., Pederson, J. R., and Fisher, J. A.: The Arctic Research of the Composition of the Troposphere from Aircraft and Satellites (ARCTAS) mission: design, execution, and first results, Atmos. Chem. Phys., 10, 5191-5212, doi:10.5194/acp-10-5191-2010, 2010.

Law, K. S. and Stohl, A.: Arctic Air Pollution: Origins and Impacts, Science, 315, 1537-1540, doi:10.1126/science.1137695, 2007.

Lopez, J. P., Luo, M., Christensen, L. E., Loewenstein, M., Jost, H., Webster, C. R., and Osterman, G.: TES carbon monoxide validation during two AVE campaigns using the Argus and ALIAS instruments on NASA's WB-57F, J. Geophys. Res., 113, D16S47, doi:10.1029/2007JD008811, 2008.

McMillan, W. W., Warner, J. X., McCourt Comer, M., Maddy, E., Chu, A., Sparling, L., Eloranta, E., Hoff, R., Sachse, G., Barnet, C., Razenkov, I., and Wolf, W.: AIRS views transport from 12 to 22 July 2004 Alaskan/Canadian fires: Correlation of AIRS CO and MODIS AOD with forward trajectories and comparison of AIRS CO retrievals with DC-8 in situ measurements during INTEX-A/ICARTT, J. Geophys. Res., 113, D20301, doi:10.1029/2007JD009711, 2008.

Mitchell Jr., J. M.: Visual range in the polar regions with particular reference to the Alaskan Arctic, J. Atmos. Terr. Phys., Special Suppl., Pt. I, 195-211, 1957.

Nedelec, P., Cammas, J.-P., Thouret, V., Athier, G., Cousin, J.-M.,
Legrand, C., Abonnel, C., Lecoeur, F., Cayez, G., and Marizy, C.: An improved infrared carbon monoxide analyser for routine measurements aboard commercial Airbus aircraft: technical validation and first scientific results of the MOZAIC III programme, Atmos. Chem. Phys., 3, 1551-1564, doi:10.5194/acp-3-15512003, 2003.

Paris, J.-D., Ciais, P., Nédélec, P., Ramonet, M., Belan, B. D., Arshinov, M. Y., Golitsyn, G. S., Granberg, I., Stohl, A., Cayez, G., Athier, G., Boumard, F., and Cousin, J. M.: The YAK-AEROSIB transcontinental aircraft campaigns: new insights on the transport of $\mathrm{CO}_{2}, \mathrm{CO}$ and $\mathrm{O}_{3}$ across Siberia, Tellus B, 60 (4), 551568, 2008.

Paris, J.-D., Stohl, A., Nédélec, P., Arshinov, M. Yu., Panchenko, M. V., Shmargunov, V. P., Law, K. S., Belan, B. D., and Ciais, P.: Wildfire smoke in the Siberian Arctic in summer: source characterization and plume evolution from airborne measurements, Atmos. Chem. Phys., 9, 9315-9327, doi:10.5194/acp-9-9315-2009, 2009.

Provencal, R., Gupta, M., Owano, T.G., Baer, D. S., Ricci, K. N., O'Keefe, A., and Podolske, J. R.: Cavity-enhanced quantumcascade laser-based instrument for carbon monoxide measurements, Appl. Optics, 44(31), 6712-6717, 2005.

Razavi, A., Clerbaux, C., Wespes, C., Clarisse, L., Hurtmans, D., Payan, S., Camy-Peyret, C., and Coheur, P. F.: Characterization of methane retrievals from the IASI space-borne sounder, Atmos. Chem. Phys., 9, 7889-7899, doi:10.5194/acp-9-7889-2009, 2009.

Rinsland, C. P., Dufour, G., Boone, C. D., Bernath, P. F., Chiou, L., Coheur, P.-F., Turquety, S., and Clerbaux, C.: Satellite boreal measurements over Alaska and Canada during June-July 2004: Simultaneous measurements of upper tropospheric $\mathrm{CO}$, $\mathrm{C}_{2} \mathrm{H}_{6}, \mathrm{HCN}, \mathrm{CH}_{3} \mathrm{Cl}, \mathrm{CH}_{4}, \mathrm{C}_{2} \mathrm{H}_{2}, \mathrm{CH}_{3} \mathrm{OH}, \mathrm{HCOOH}, \mathrm{OCS}$, and SF6 mixing ratios, Global Biogeochem. Cy., 21, GB3008, doi:10.1029/2006GB002795, 2007.

Rodgers, C. D.: Inverse methods for atmospheric sounding: theory and practice, Ser. Atmos. Ocean. Planet. Phys. 2, World Sci., Hackensack, NJ, 2000.

Rodgers, C. D. and Connor, B. J.: Intercomparison of remote sounding instruments, J. Geophys. Res., 108(D3), 4116, doi:10.1029/2002JD002299, 2003.

Sachse, G. W. ,Hill, G. F., Wade, L. O., and Perry, M. G.: Fast response, high precision carbon monoxide sensor using a tunable diode laser absorption technique, J. Geophys. Res., 92, 20712081, 1987.

Schlüssel, P., Hultberg, T. H., Phillips, P. L., August, T., and Calbet, X.: The operational IASI Level 2 processor, Adv. Space Res., 36 , 982-988, 2005.

Shindell, D., Faluvegi, G., Lacis, A., Hansen, J., Ruedy, R., and Aguilar, E.: Role of tropospheric ozone increases in 20th-century climate change, J. Geophys. Res., 111, D08302, doi:10.1029/2005JD006348, 2006.

Shindell, D. T., Chin, M., Dentener, F., Doherty, R. M., Faluvegi, G., Fiore, A. M., Hess, P., Koch, D. M., MacKenzie, I. A., Sanderson, M. G., Schultz, M. G., Schulz, M., Stevenson, D. S., Teich, H., Textor, C., Wild, O., Bergmann, D. J., Bey, I., Bian, H., Cuvelier, C., Duncan, B. N., Folberth, G., Horowitz, L. W., Jonson, J., Kaminski, J. W., Marmer, E., Park, R., Pringle, K. J., Schroeder, S., Szopa, S., Takemura, T., Zeng, G., Keating, T. J., and Zuber, A.: A multi-model assessment of pollu- 
tion transport to the Arctic, Atmos. Chem. Phys., 8, 5353-5372, doi:10.5194/acp-8-5353-2008, 2008.

Sodemann, H., Pommier, M., Arnold, S. R., Monks, S. A., Stebel, K., Burkhart, J. F., Hair, J. W., Diskin, G. S., Clerbaux, C., Coheur, P.-F., Hurtmans, D., Schlager, H., Blechschmidt, A.-M., Kristjánsson, J. E., and Stohl, A.: Episodes of cross-polar transport in the Arctic troposphere during July 2008 as seen from models, satellite, and aircraft observations, Atmos. Chem. Phys. Discuss., 10, 26361-26410, doi:10.5194/acpd-10-26361-2010, 2010.

Stohl, A.: Characteristics of atmospheric transport into the Arctic troposphere, J. Geophys. Res., 111, D11306, doi:10.1029/2005JD006888, 2006.

Turquety, S., Logan, J. A., Jacob, D. J., Hudman, R. C., Leung, F. Y., Heald, C. L., Yantosca, R. M., Wu, S., Emmons, L. K., Edwards, D. P., and Sachse, G. W.: Inventory of boreal fire emissions for North America in 2004: the importance of peat burning and pyro-convective injection, J. Geophys. Res., 112, D12S03, doi:10.1029/2006JD007281, 2007.

Turquety, S., Clerbaux, C., Law, K., Coheur, P.-F., Cozic, A., Szopa, S., Hauglustaine, D. A., Hadji-Lazaro, J., Gloudemans, A. M. S., Schrijver, H., Boone, C. D., Bernath, P. F., and Edwards, D. P.: $\mathrm{CO}$ emission and export from Asia: an analysis combining complementary satellite measurements (MOPITT, SCIAMACHY and ACE-FTS) with global modeling, Atmos. Chem. Phys., 8, 5187-5204, doi:10.5194/acp-8-5187-2008, 2008.
Turquety, S., Hurtmans, D., Hadji-Lazaro, J., Coheur, P.-F., Clerbaux, C., Josset, D., and Tsamalis, C.: Tracking the emission and transport of pollution from wildfires using the IASI CO retrievals: analysis of the summer 2007 Greek fires, Atmos. Chem. Phys., 9, 4897-4913, doi:10.5194/acp-9-4897-2009, 2009.

Wan, Z.: New refinements and validation of the MODIS landsurface temperature/emissivity products, Remote Sens. Environ., 112, 59-74, 2008.

Warneke, C., Bahreini, R., Brioude, J., Brock, C. A., de Gouw, J. A. , Fahey, D. W. , Froyd, K. D. , Holloway, J. S., Middlebrook, A., Miller, L., Montzka, S., Murphy, D. M., Peischl, J., Ryerson, T. B., Schwarz, J. P., Spackman, J. R., and Veres, P.: Biomass burning in Siberia and Kazakhstan as an important source for haze over the Alaskan Arctic in April 2008, Geophys. Res. Lett., 36, L02813, doi:10.1029/2008GL036194, 2009.

Wespes, C., Hurtmans, D., Clerbaux, C., Santee, M. L., Martin, R. V., and Coheur, P. F.: Global distributions of nitric acid from IASI/MetOP measurements, Atmos. Chem. Phys., 9, 7949-7962, doi:10.5194/acp-9-7949-2009, 2009.

Yurganov, L. N., McMillan, W. W., Dzhola, A. V., Grechko, E. I., Jones, N. B., and van der Werf, G. R.: Global AIRS and MOPITT CO measurements: Validation, comparison, and links to biomass burning variations and carbon cycle, J. Geophys. Res., 113, D09301, doi:10.1029/2007JD009229, 2008. 